\title{
The formation mechanism of authigenic chlorite in tight sandstone and its effect on tight oil adsorption during hydrocarbon filling
}

Qianshan Zhou ${ }^{1,2}$, Chao $\mathrm{Li}^{1,2, *}$, Guojun Chen ${ }^{1,2}$, Chengfu Lyu ${ }^{1,2}$, Xuefeng $\mathrm{Qu}^{3,4}$, Xiaofeng Ma ${ }^{1}$, Chengze $\mathrm{Li}^{1,5}$, Qihong $\mathrm{Lei}^{3,4}$, and Qichao Xie ${ }^{3,4}$

\footnotetext{
${ }^{1}$ Northwest Institute of Eco-Environment and Resources, Chinese Academy of Sciences, Lanzhou 730000, China

${ }^{2}$ Key Laboratory of Petroleum Resources Research, Gansu Province, Lanzhou 730000, China

${ }^{3}$ PetroChina Changqing Oil Field Company, Xi'an 710000, China

${ }^{4}$ National Engineering Laboratory for Exploration and Development of Low-Permeability Oil\&Fields, Xi'an 710000, China

${ }^{5}$ University of Chinese Academy of Sciences, Beijing 100049, China
}

Received: 21 May 2020 / Accepted: 17 March 2021

\begin{abstract}
Authigenic chlorite, which is frequently found in sandstone, has a controlling effect on the reservoirs in which tight oil is adsorbed during hydrocarbon filling. In this study, the content, occurrence state, timing, mechanism and influence of authigenic chlorite on the micro-occurrence states of tight oil were studied using Thin Section (TS), Fluorescent Thin Section (FTS), X-Ray Diffraction (XRD), Field Emission-Scanning Electron Microscopy (FE-SEM), Environmental Scanning Electron Microscopy (ESEM), and Energy Dispersive Spectroscopy (EDS). The results indicate: (1) a spatial coupling between chlorite development, a brackish water delta front facies depositional environment, and biotite-rich arkosic sandstone. (2) Authigenic chlorite can be divided into three types: grain-coating chlorite, pore-lining chlorite, and rosette chlorite. Chlorite forms after early compaction but before other diagenetic phases, and grows via precipitation from pore waters that contain products released during the dissolution of volcanic rock fragments and biotites. Porewater is also pressurereleased from feldspars and mudstone. (3) The micro-occurrence states of tight oil can be divided into five types: emulsion form, cluster form, throat form, thin-film form, and the isolated or agglomerated particle form. (4) During hydrocarbon filling, tight oil mainly occurs on the surface of grain-coating and pore-lining chlorite in the form of a thin film, the granular or agglomerated forms are mainly enriched within the intercrystalline pores within the authigenic chlorite, and the cluster forms are mainly enriched in dissolution pores. Isolated or agglomerated particles of tight oil primarily occur in the intercrystalline pores of the rosette chlorite. (5) The specific surface area and the authigenic chlorite's adsorption potential of authigenic chlorite control the micro-occurrence of tight oil on the surface of the chlorite and in intercrystalline pores. The adsorption capacity of chlorite lies in the following order: pore-lining chlorite intercrystalline pores $>$ rosette chlorite $>$ chlorite in feldspar dissolution pores $>$ pore-lining chlorite surface $>$ grain-coating chlorite intercrystalline pores $>$ grain-coating chlorite surface.
\end{abstract}

\section{Introduction}

With the successful exploration and development of unconventional oil and gas sources, tight oil and gas have increased in importance in the global energy market and become the priority choice for alternate energy generation (Al-Otaibi et al., 2015; Denne et al., 2014; Jia et al., 2012; Kuhn et al., 2012; Landon et al., 2001; LeFever et al., 2013; Sonnenberg and Pramudito, 2009; Sonnenberg, 2015, 2017; Sonnenberg et al., 2018; Wu et al., 2016, 2018; Zou et al., 2011, 2012a, 2012b). Chlorite is an essential

\footnotetext{
* Corresponding author: lichaomails@lzb.ac.cn
}

diagenetic mineral that forms in tight sandstone reservoirs, and its content, morphology and occurrence characteristics play crucial roles in reservoir control. Authigenic chlorite affects the preservation of primary pores, the development of secondary pores, and the performance and seepage capacity of a reservoir, especially lacustrine tight sandstone reservoirs (Berger et al., 2009; Ding et al., 2010; Grigsby, 2001; Huang et al., 2004; Lan et al., 2011; Tian et al., 2008; Yang et al., 2012). Authigenic chlorite is widely distributed in Mesozoic-Cenozoic lacustrine sandstone reservoirs, such as the Triassic and Jurassic area of Sichuan Basin, the Tertiary region in Subei Basin, and the TurpanHami Basin. Pore-ring lining is produced in most basins, including the Jurassic and Tertiary area in Nanzhao Basin, 
the Songliao Basin, and the Ordos Basin (Huang et al., 2004).

Chlorite is known to format at low temperature $\left(80-90{ }^{\circ} \mathrm{C}\right)$, in prograde metamorphic rocks, and as the retrograde alteration products of ferroan metamorphic minerals (Worden et al., 2020). It is generally believed that the formation of grain-coating chlorite begins before the compaction and consolidation of clastic particles, while the formation of pore-lining chlorite continues throughout diagenesis. The paleo-climatic environment during deposition, the fluid nature of the burial diagenesis stage, the weathering of terrigenous volcanic rocks, and the dissolution of lithic debris are all considered to be important factors that control the formation of chlorite. The supply of iron-magnesium-rich materials and the geochemical conditions of the fluid control the growth of authigenic chlorite, which is predominantly precipitated in diagenetic fluids with a high $\mathrm{pH}$ (alkali-rich environment) that are rich in $\mathrm{Fe}^{2+}$ and $\mathrm{Mg}^{2+}$ (Zhang et al., 2012; Worden et al., 2020). Sufficient volcanic material supply is considered to be one of the most important conditions surrounding the formation of large amounts of authigenic chlorite; this is particularly true of volcanic events, which may have had a significant impact on the precipitation of chlorite during the Mesozoic-Cenozoic periods in the Ordos Basin (Zhang et al., 2012; Ma et al., 2017a, 2017b). The wide distribution of the Mesozoic-Cenozoic lacustrine sandstone reservoirs means that these features can provide important information on the fluid evolution, chemical composition changes, and diagenetic evolutionary processes that occurred in reservoirs. Previous studies investigating authigenic chloride have mainly focused on its content, occurrence, and distribution (Tian et al., 2008), which also association with the preservation of primary reservoir pores, the formation time, the mechanisms involved, and the modification of the physical properties of a reservoir (Ding et al., 2010; Huang et al., 2004; Lan et al., 2011).

Chlorite has been of interest to petroleum geologists for well over 50 years, ever since its association with deeplyburied sandstones became apparent (Heald and Anderegg, 1960; Pittman and Lumsden, 1968; Zhang et al., 2012; Ma et al., 2017a, 2017b; Worden et al., 2020). However, some texts and primary sources of geological and mineralogical information neglect the effect that chlorite is an essential constituent of many sedimentary and diagenetic systems (King, 2019), and that it can affect the reservoir fluid environment of a reservoir during hydrocarbon filling. Therefore, it is necessary to study the adsorption behaviour of chlorite during the process of crude oil charging in chlorite-based pore wall media, which is the focus of this research.

Nanopores are virtual spaces in which tight oil can form (Gong et al., 2015; Zou et al., 2011, 2012a, 2012b), and the adsorption of tight oil onto the surface of a mineral is essential in tight oil reservoirs. Analyses of the space in tight reservoirs and mineral composition characteristics have determined that the micro-occurrence of tight oil is different from that of conventional oil and gas (Zou et al., 2012a, 2012b). Recent research characterising the occurrence of tight oil has mainly focused on the macroscopic oil-water distribution relationship (Tong et al., 2011). Microscopic fluorescence identification has been used to determine the occurrence of tight oil in reservoirs (Huangfu et al., 2003) and the characteristics of hydrocarbon distribution under different fractional fragmentation phase fractional extraction (Shi et al., 2005; Wang et al., 2010) have been studied. However, the experimental methods used in these studies are relatively simple, and cannot systematically describe the characteristics of tight oil on a microscopic scale. Therefore, it is necessary to improve the experimental method to better characterize the micro-occurrence state of absorbed tight oil.

Wang et al. (2015) analyzed the micro-existing states (adsorption of tight oil onto the surface of rocks) of tight oil in the Chang 7 Member of the Triassic Yanchang Formation in the Ordos Basin using micrometer-nanometer CT scanning technology and divided the micro-occurrence characteristics of the tight oil in the reservoirs into six types. Gong et al. (2015) used ESEM to characterize the occurrence state of tight oil in micro-and nanopores of tight sands in Member 4 of the Cretaceous Quantou Formation and classified the occurrence state of tight oil into two primary forms: films and droplets.

This study focuses on the influence that authigenic chlorite has on the micro-occurrence of tight oil and aims to establish the relationship between authigenic chlorite and the micro-occurrence characteristics of tight oil to supplement the theories on the adsorption of tight oil by authigenic chlorite during the hydrocarbon filling process and its subsequent modification effect on the reservoir.

\section{Geological setting}

The Ordos Basin is a Mesozoic and Cenozoic large-scale continental lake sedimentary basin that is located on the western margin of the North China Platform in eastern China, covering an area of approximately $25 \times 10^{4} \mathrm{~km}^{2}$. It is a large cratonic superimposed basin that has undergone both multi-tectonic system and multi-cycle evolution (Fig. 1). Huaqing area is located in the southwestern part of the basin and is mainly controlled by the northern Shanxi slope. It is a simple monocline with an average structural slope of 1/100 (Ding et al., 2010) and has a series of lowamplitude nose structures that have developed within. The oil and gas accumulation is not related to the structure but is mainly associated with lithologic reservoirs. The Yanchang Formation is the main target layer for oil and gas exploration and development in this area with its hydrocarbon source rock characteristics, matching sourcereservoir-cap assemblages, and wide exploration field; the formation is considered to have significant potential in terms of petroleum resources (Fu, 2018; Yang and Zhang, 2005). Volcanic materials from the same period are widely distributed among the sandstones of the Yanchang Formation. The residual feldspar is mainly albite (or acidic plagioclase), and there is albitization of the plagioclase (Ma et al., 2017b). Enrichment with these rock minerals is conducive to the development of authigenic chlorite.

The Yanchang Formation has experienced multiple water inflow and water recession stages, which has led to 


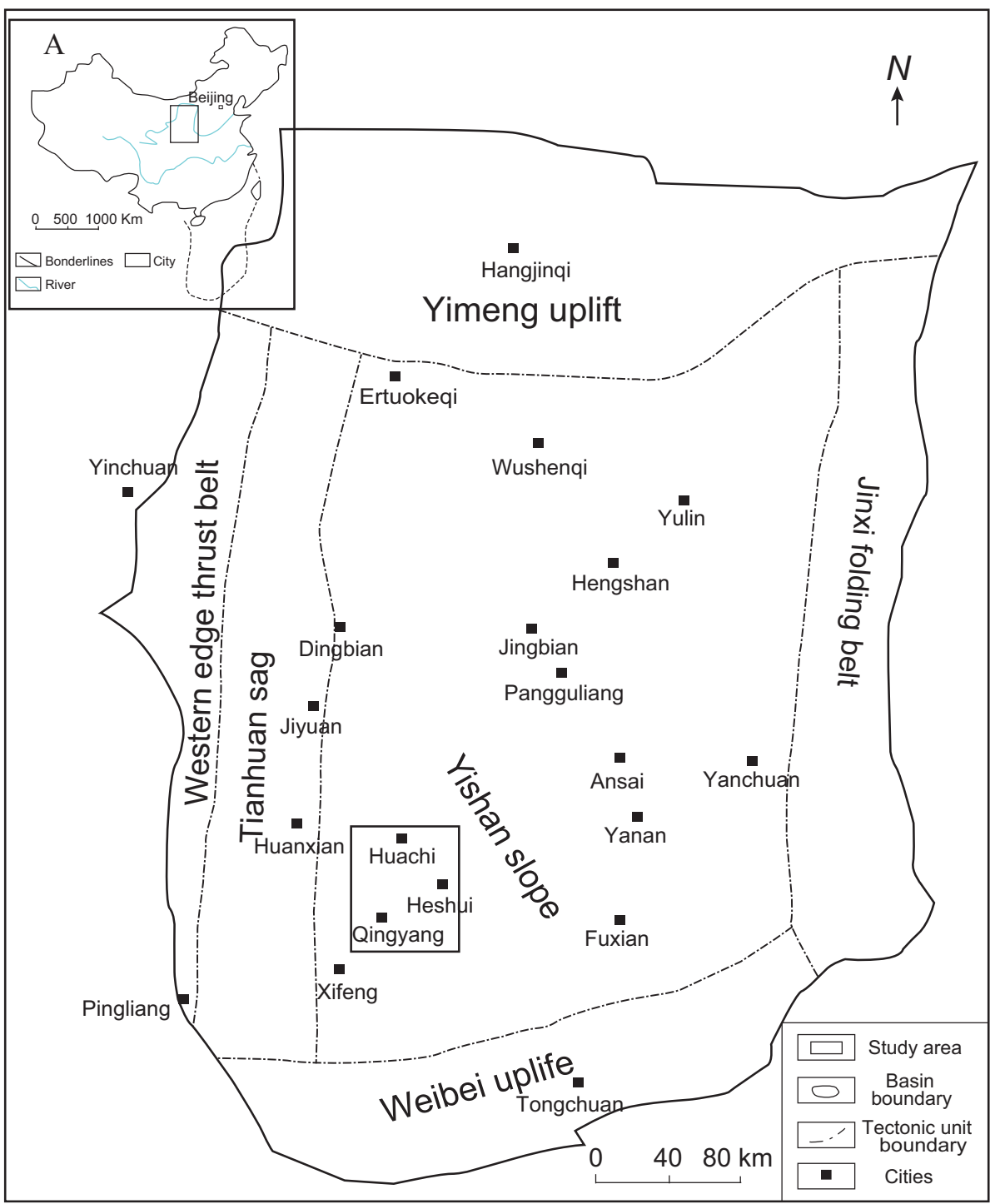

Fig. 1. The structural location of the study area (modified from Li et al., 2018).

the development of several sandstones and mudstones, of which the Chang 8 tight oil reservoir is the leading exploration and development horizon (Fig. 2). The Huaqing area comprises a braided river delta front sub-facies that is divided into underwater distributary channel sandstones, estuary bar sandstones, and distal bar sandstones, and the sandstone lithology of Chang 8 in Huaqing is mainly medium-fine lithic feldspar sandstone followed by mediumfine lithic feldspar sandstone. These sandstones have medium structural maturity, medium-good sorting, and mainly show subangular roundness with dominant pointline contact between grains. The contents of quartz, feldspar, and debris are $21.8-43.5 \%, 14-26.8 \%$, and $19.6-$ $36.7 \%$, respectively. The cement mainly comprises clay minerals, carbonate minerals, and silica, with contents ranging from $11.2 \%$ to $16.3 \%$, and the clay minerals are mainly composed of chlorite, with contents ranging from $6.9 \%$ to $11.8 \%$ (Ding et al., 2010).

\section{Materials and methods}

\subsection{Samples}

Tight oil is known to have developed in the Chang 8 Members of the Triassic Yanchang Formation in the southwestern part of Ordos Basin. Eight reservoir samples were comprised of five oil-immersed sandstones, one oil-porphyry sandstone, and two oil-trace sandstones were collected (Tab. 1). The porosity and permeability of samples were in the ranges of $9.69-15 \%$ and $0.096 \times 10^{-3} \mu \mathrm{m}^{2}-1.25 \times$ $10^{-3} \mu^{2}$, respectively.

In this study, X-Ray Diffraction (XRD), Field Emission Scanning Electron Microscopy (FE-SEM), and Thin Sections (TS) were used to clarify the content, occurrence, and formation mechanism of the authigenic chlorite in the Chang 8 Member. In addition, the micro-occurrence states of the tight oil in different chlorites were characterized using 


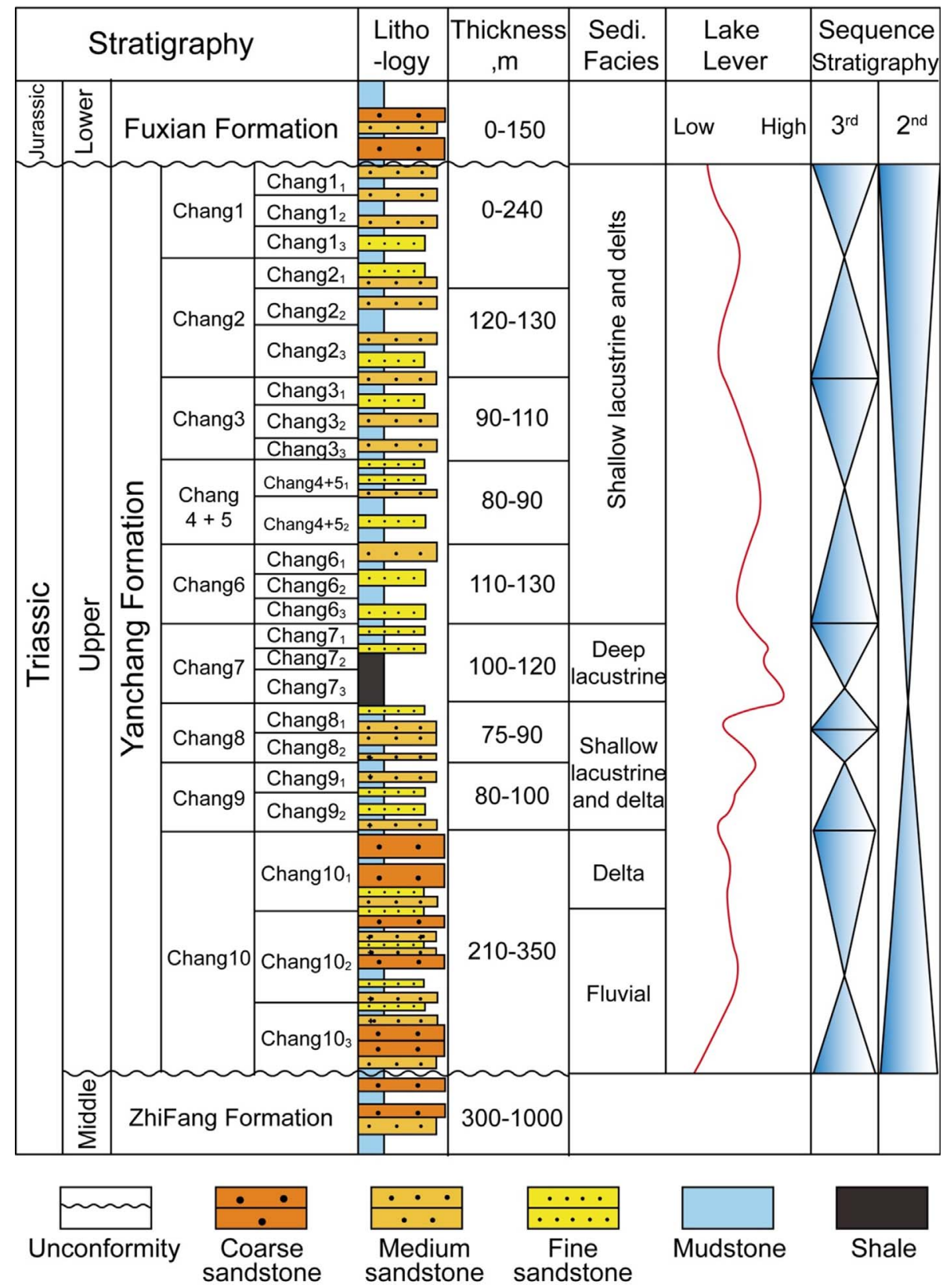

Fig. 2. Comprehensive stratigraphic column of the study area (modified from Zhou et al., 2016).

an Environmental Scanning Electron Microscope (ESEM) and Energy Dispersive Spectroscopy (EDS).

\subsection{Experimental methods}

The samples were tested for helium porosity and nitrogen permeability using a Pore PDP-200 automatic porosity and permeability measuring instrument under a confining pressure of approximately $70 \mathrm{MPa}$, following standard $\mathrm{SY} / \mathrm{T}$ 6385-2016 for China. The maximum porosity was $40 \%$ with a relative error of less than $0.01 \%$, and the maximum permeability was $10 \times 10^{-3} \mu \mathrm{m}^{2}$ with a relative error of $0.00001 \times 10^{-3} \mu^{2}$.
Field Emission-Scanning Electron Microscopy (FESEM) with an accelerating voltage and resolution of $20 \mathrm{~V}-$ $30 \mathrm{kV}$ and $1.6 \mathrm{~nm}$, respectively, was used to observe the surface morphology of the tested samples following the SY/T5614-2011 standard of China. All samples were treated with mechanical polishing to produce fresh surfaces that were used to observe the geometrical morphology of the pores and minerals. The hydrocarbon-bearing properties were determined according to differences in the fluorescent colours, brightness, and the luminous sites of the hydrocarbons and other organic matter in the rocks under ultraviolet excitation, and samples were identified using a Nikon 80i, THMGS 600, Maya 2000 pro three-channel advanced 
Table 1. Information of tight sandstone samples in Huaqing area.

\begin{tabular}{|c|c|c|c|c|c|c|c|}
\hline Sample & Depths/m & Porosity $/ \%$ & $\begin{array}{l}\text { Permeability/ } \\
\quad \times 10^{-3} \mu \mathrm{m}^{2}\end{array}$ & $\begin{array}{l}\text { Pore throat } \\
\text { median } \\
\text { radius } / \mathrm{nm}\end{array}$ & $\begin{array}{c}\text { Reservoir } \\
\text { types }\end{array}$ & Lithology & $\begin{array}{c}\text { Cores } \\
\text { oil-bearing } \\
\text { level }\end{array}$ \\
\hline $\mathrm{S} 2$ & 2138.1 & 15 & 1.25 & 850 & 1 & $\begin{array}{l}\text { Gray-brown fine } \\
\text { sandstone }\end{array}$ & Immersion \\
\hline S3 & 2192.6 & 11.08 & 0.521 & 200 & 3 & $\begin{array}{l}\text { Gray-brown fine-silt } \\
\text { sandstone }\end{array}$ & Immersion \\
\hline $\mathrm{S} 4$ & 2174.53 & 12.4 & 0.096 & 80 & 4 & Gray-brown siltstone & Oil trace \\
\hline S5 & 2242.4 & 10.2 & 0.406 & 430 & 3 & Gray fine sandstone & Oil spotf \\
\hline S6 & 2235.6 & 9.69 & 0.11 & 370 & 4 & Gray-brown siltstone & Oil trace \\
\hline S7 & 2062.2 & 11.18 & 0.74 & 790 & 2 & Gray fine sandstone & Immersion \\
\hline S8 & 2287.45 & 11.68 & 0.568 & 465 & 3 & $\begin{array}{l}\text { Gray-brown fine } \\
\text { sandstone }\end{array}$ & Immersion \\
\hline S9 & 2189.4 & 13 & 0.524 & 730 & 3 & $\begin{array}{l}\text { Gray-brown fine } \\
\text { sandstone }\end{array}$ & Immersion \\
\hline
\end{tabular}

fluorescence microscope under standard the SY/T5614-2011 of China. X-Ray Diffraction (XRD) was conducted using a Rigaku Ultima type IV X-ray diffractometer from Japan $(\mathrm{Cu} \mathrm{K} \alpha, \lambda=0.154 \mathrm{~nm})$, in accordance with standard SY/T 5163-2010 (Wu et al., 2018; Zeng et al., 2010).

Environmental Scanning Electron Microscopy (ESEM) was used under a low vacuum mode to observe the pores and throats of the oil-bearing sandstone on a micronanometre scale. The micro occurrence was characterized simultaneously. X-ray Energy Dispersive Spectroscopy (EDS) was used in conjunction with ESEM to quantitatively determine the carbon content of the hydrocarbons in the detection range of one to several microns (Gong et al., 2015). A Quanta FEG450 Environmental Scanning Electron Microscope (ESEM) in low-vacuum mode with a chamber pressure and a working voltage of $10 \mathrm{~Pa}, 15 \mathrm{kV}$, respectively, was adopted to prevent the destruction of the original occurrence state of the tight oil. An electron beam spot of $4.5 \mathrm{~nm}$ (corresponding beam current value is $7 \mathrm{nA}$ ), and an operating temperature of $20{ }^{\circ} \mathrm{C}$ were used for this process. An Ultra-Thin Window (UTW) detector was used in the spectrometer to detect elements with an atomic number between $4(\mathrm{Be})$ and $92(\mathrm{U})$, and the peak value of the same elements in each same sample positively correlated with their content. The differences between the structure of the micropore throat and the oil and gas filling process in the different samples mean that these factors should not be compared. The experimental samples were produced using well-oil-bearing core samples $(1 \mathrm{~cm} \times 1 \mathrm{~cm})$ with the fresh oil-bearing surface rapidly knocked out and placed in the electron microscope observation chamber to ensure that hydrocarbons were not lost during the observation process. During the observation process, the corresponding magnification was adjusted to observe any tight oil that was present in the micron-nano-scale pore throats or on the surfaces of mineral particles during observation.

All the experiments were completed at the Lanzhou Oil and Gas Resource Center, Northwest Institute of EcoEnvironment and Resources, Chinese Academy of Sciences.

\section{Results}

\subsection{Occurrence forms of authigenic chlorite}

The chlorite in the Chang 8 Member of the Triassic Yanchang Formation in the Huaqing area of the Ordos Basin occurs as both authigenic chlorite and altered chlorite. According to the Thin Section (TS) and Field Emission Scanning Electron Microscopy (FE-SEM) observation of authigenic chlorite crystals and their contact with mineral particles, there are three occurrence types of authigenic chlorite: grain-coating chlorite, pore-lining chlorite, and rosette chlorite, which are present in the formation (Jeffry, 2001). These are described below.

\section{Grain-coating chlorite}

This type of chlorite is most common in the study area and is mainly distributed on the surface of particles (Huang et al., 2004). Single chlorite crystals are tiny and lie parallel or oblique to the particle surface at particle-pore contact points and parallel to the particle surface at the particle-particle contact points (Billault et al., 2003). Grain-coating chlorite is frequently wraped the surface of particles in a thin film form of 1-8 $\mu \mathrm{m}$ in thickness (Fig. 3a).

2. Pore-lining chlorite

This type of chlorite is the primary form of authigenic chlorite. It mainly enwraps particle surfaces, only grows on the surface of granules, and has the same pore contact as the grain-coating forms. Chlorite crystals grow vertically towards the center of the pore in a sheet-shape on the surface of the particles or vertically towards the direction of the pore in a leaf- or needleshapes that form on the inner coating. The closer they are to the pore, the better the self-organisation and the thinner the leaves. Pore-lining chlorite is generally 3-10 $\mu \mathrm{m}$ thick, but can reach up to $16 \mu \mathrm{m}$ (Fig. 3b), and is mainly distributed in residual intergranular pores and intergranular dissolution pores. 

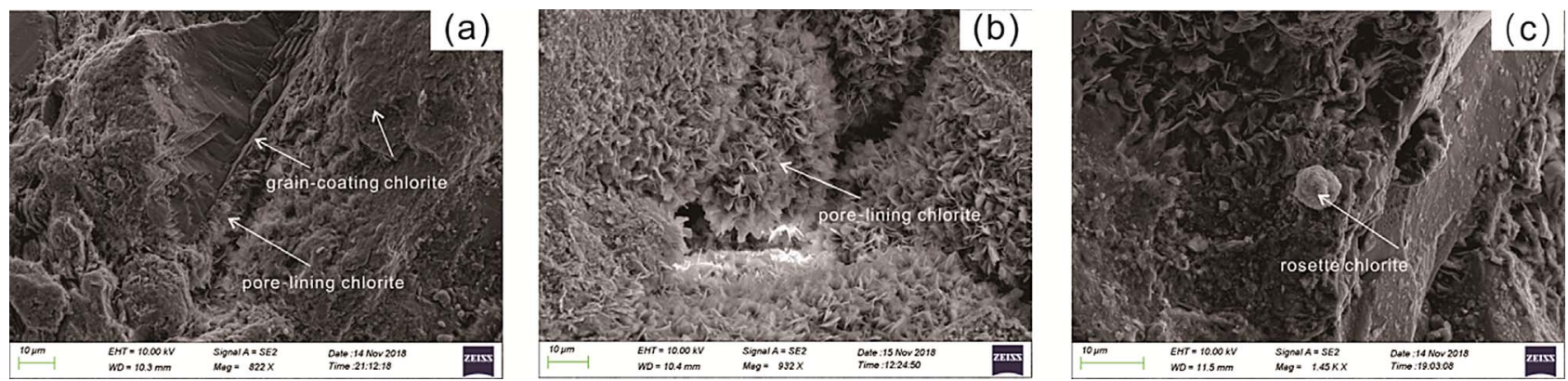

Fig. 3. FE-SEM characteristics of different chlorite occurrence states (a) grain-coating chlorite, S6, 2235.6 m; (b) pore-lining chlorite, S3, $2192.6 \mathrm{~m}$; (c) rosette chlorite, S7, $2062.2 \mathrm{~m}$.

\section{Rosette chlorite}

Rosette chlorite covers the surface of particles either directly or as pore-lining chlorite. It is high selforganisation, presents as a rosette aggregate (Fig. 3c), is often distributed in pores, and has no inherited growth relationship with granular encapsulated chlorite. The rosette chlorite in the study area was $5 \mu \mathrm{m} \times 12 \mu \mathrm{m}-12 \mu \mathrm{m} \times 18 \mu \mathrm{m}$ in size, and filled the remaining primary intergranular pores first, followed by the dissolved pores.

\subsection{Micro-occurrence characteristics of tight oil}

The micro-occurrence characteristics in the Chang 8 reservoir were characterized based on the experimental methods of fluorescence thin section identification and the ESEM observations combined with a quantitative determination of the hydrocarbon carbon content obtained by Energy Dispersive Spectroscopy (EDS). According to the statistical analysis and examination of 96 fluorescence images and 280 energy dispersive spectrum test points of eight samples, the micro-occurrence forms of tight oil in the study area can be divided into five forms: an emulsion form, cluster form, throat form, thin film form and isolated or agglomerated particles (Fig. 4).

The emulsion form mainly occurs in the intergranular pores with discontinuous impregnation and adhesion (Figs. 4a1 and 4a2). The colours produced by emulsion fluorescence are generally brighter under fluorescent thin section analysis, darkening from the surface of the particles to the centre of pores. There is an increase in pore connectivity, and zonation is observed in the distribution of the compact oil in the pores. Most of the tight oil in emulsion form has a high carbon content (Fig. 4a3). The peak carbon content of the tight oils measured by EDS was much higher than that of other elements, with the proportion of carbon elements at $45-78 \%$.

The throat form is mainly distributed in discontinuous strips between the inter-particle throat and the rock fissure, the fluorescence is mainly pale green and orange-red, and the colour is brighter at the center of the throat than it is at the two sides. Under ESEM observation, tight oil is mostly produced in the form of a thin lining, with a darker colour on both sides of the throat and a higher carbon content (Figs. 4b1-4b3), and the peak carbon content of tight oil measured by EDS is much lower than that of the emulsion form. The proportion of carbon elements in this form is $7-34.79 \%$.

The cluster form is mainly distributed within the dissolution pores in the feldspar and the carbonate cement. It is concentrated in dense spots under a fluorescent thin sections, with a dark fluorescence colour (Fig. 4c1). ESEM shows that it is mostly produced in the form of tight oil that lines the feldspar dissolution holes; the colour is deeper at the edge of the feldspar dissolution holes, and the carbon content is higher (Figs. 4c2 and 4c3). The results of EDS show that the proportion of cluster form is $6.7-20.7 \%$, and that its distribution varies over a broad range.

The thin film form is mainly distributed at the edge of particles about the distribution of the chlorite coating. It mainly appears in the form of light green or black rings of different thicknesses (Fig. 4d1) and is mainly controlled by the distribution of the grain-coating chlorite. Tight oil mainly occurs on the surface of chlorite particles in the form of a thin film, the thickness of which is mostly controlled by the thickness of the chlorite. EDS shows that the proportion of the carbon element is $3.32-13.86 \%$ (Figs. $4 \mathrm{~d} 2$ and $4 \mathrm{c} 3$ ).

The isolated or agglomerated particulate forms are mainly distributed in the isolated intercrystalline pores or the calcite cement. Fluorescent thin section analysis shows that this form is mostly distributed on the edges of quartz and feldspar particles (Figs. 4e1 and 4e2). The fluorescent colours of the isolated or agglomerated particle forms were mainly orange-red, light green, and light yellow. Organic rings, thin films, and aggregates on the surface of the cement and the intercrystalline pores were observed under ESEM analysis. EDS shows that the proportion of carbon is widely distributed between $3.4 \%$ and $52.25 \%$ (Fig. 4 e3).

\section{Discussion}

\subsection{Formation mechanism of authigenic chlorite}

Authigenic chlorite is produced during diagenesis, with a generally relatively complete crystal shape is generally relatively complete, with sharp edges and corners and clear edges (Zhang et al., 2012; Ma et al., 2017a, 2017b; Worden et al., 2020). Chlorite is a layered silicate mineral that forms in an iron-rich, alkaline-reduction environment (Anjos et al., 1999; Huang et al., 2004; Huggett et al., 2015; 

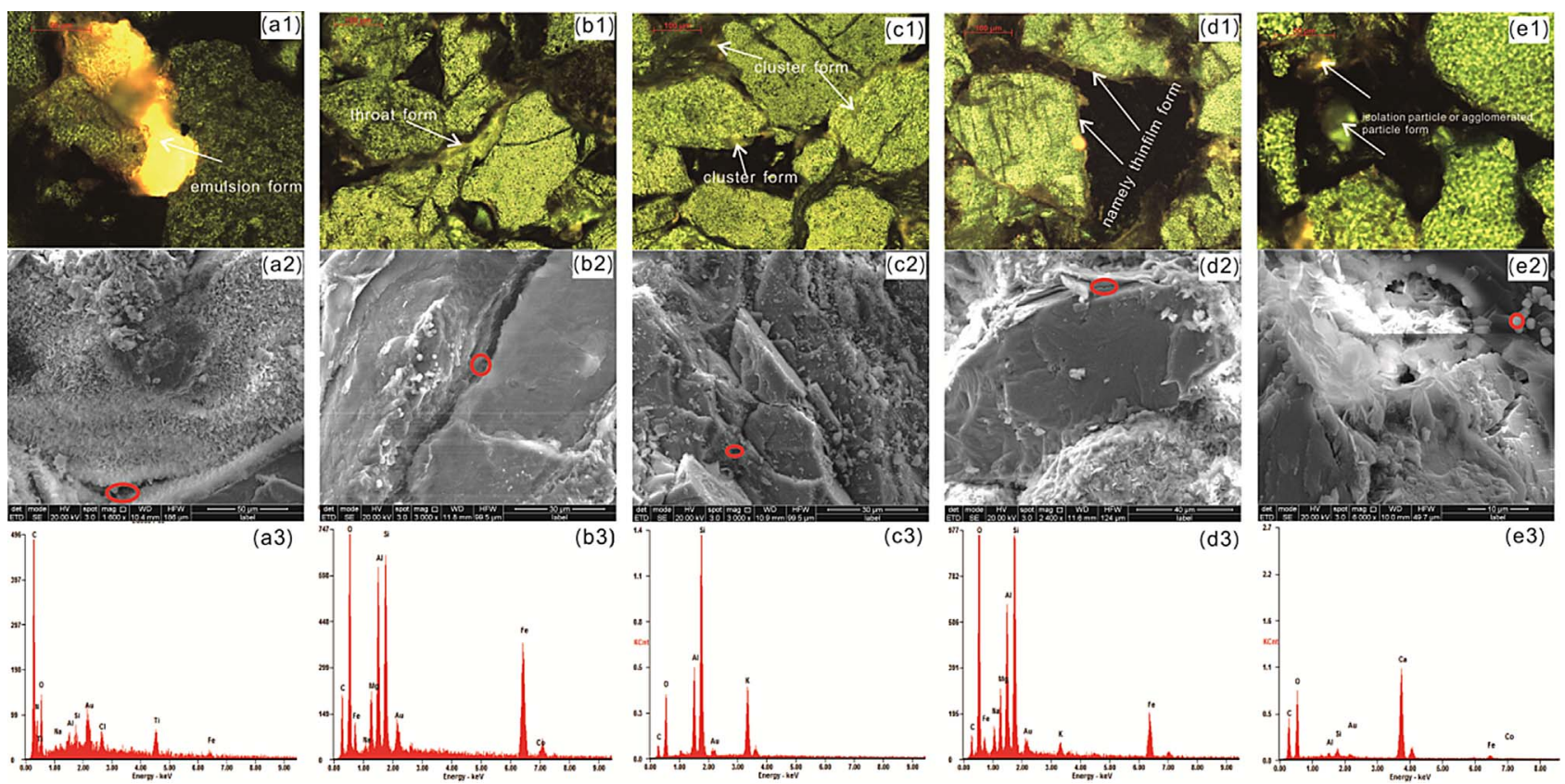

Fig. 4. Characteristics of compact oil in different occurrence states (a1) - (a3) are the micro-occurrence characteristics of emulsion form of tight oil under fluorescent thin section, ESEM and EDS, respectively, S2, 2138.1 m; (b1) - (b3) are the micro-occurrence characteristics of throat form of tight oil under fluorescent thin section, ESEM and EDS, respectively, S3, 2192.6 m; (c1) - (c3) are the micro-occurrence characteristics of cluster form of tight oil under fluorescent thin section, ESEM and EDS, respectively, S9, 2189.4 m; $(\mathrm{d} 1)-(\mathrm{d} 3)$ are the micro-occurrence characteristics of namely thin form of tight oil under fluorescent thin section, ESEM and EDS, respectively, S6, 2235.6 m; (e1) - (e3) are the micro-occurrence characteristics of isolation particle or agglomerated particle form of tight oil under fluorescent thin section, ESEM and EDS, respectively, S3, $2192.6 \mathrm{~m}$.

Worden et al., 2020). Previous studies have suggested that the iron and magnesium ions sources for authigenic chlorite are mainly derived in three ways: (1) when there are abundant dissolved iron in the water during sedimentation, that are preserved in the pore water during sedimentation (Huang et al., 2004). The hydrolysis of flocculated iron-rich colloids during the same sedimentary period can provide many iron ions. Furthermore, the dehydration of mudstone can lead to the release of iron and magnesium ions during sedimentation under the action of the overlying formation pressure (Tian et al., 2008). (2) The hydrolysis of iron-rich and magnesium-rich minerals, such as biotite, amphibole, and iron-rich tuff, releases large amounts of iron and magnesium ions (Tian et al., 2008). For example, biotite is susceptible to various diagenetic factors such as temperature, pressure, and fluid under formation conditions, which are mostly associated with the adsorption of formation water, biotite particles $\left(\mathrm{K}\left\{(\mathrm{Mg}, \mathrm{Fe})_{3}\left[\mathrm{AlSi}_{3} \mathrm{O}_{10}\right](\mathrm{OH})_{2}\right\}\right)$, it absorbs water along its cleavage joint. It simultaneously reacts with the $\mathrm{Mg}^{2+}$ rich formation water to exchange substances. In this respect, $\mathrm{Mg}^{2+}$ replaces $\mathrm{K}^{+}$and $\mathrm{Fe}^{2+}$ ions in the biotite crystal, and formation water, after which the biotite is thus transformed into chlorite $\left(\mathrm{Mg}_{5}\left[\mathrm{AlSiO}_{10}\right](\mathrm{OH})_{6}\right)$. The complex chemical reaction formula is shown in formula (1). A large amount of pyroclastic material developed in the study area, of which biotite has the highest content, meaning that a large number of chlorite formation processes based on the conversion of biotite occurred. This phenomenon was also observed under microscopy (Fig. 4). (3) Soluble minerals, such as feldspar, can be dissolved during deposition, which is then followed by changes in the chemical properties of the fluids. Early formation water is rich in iron and magnesium ions and thus promotes the alteration of potassium feldspar. The increase in burial depth and ground temperature in a weakly alkaline formation that is rich in magnesium ions can therefore lead to the transformation of potassium feldspar. The complex chemical reaction is shown in equation (2),

$$
\begin{gathered}
\mathrm{K}\left\{(\mathrm{Mg}, \mathrm{Fe})_{3}\left[\mathrm{AlSi}_{3} \mathrm{O}_{10}\right](\mathrm{OH})_{2}\right\}+\mathrm{Mg}^{2+}+\mathrm{H}_{2} \mathrm{O} \rightarrow \\
(\text { Biotite })\left(\mathrm{Fe}_{14} \mathrm{Mg}_{12} \mathrm{Al}_{2.5}\right)\left(\mathrm{Al}_{0.7} \mathrm{Si}_{3.3}\right) \mathrm{O}_{10}(\mathrm{OH})_{8} \\
+\mathrm{Fe}^{2+}+\mathrm{K}^{+}+\mathrm{H}^{+}(\text {Chlorite }) \\
\mathrm{KAlSi}_{3} \mathrm{O}_{8}+\mathrm{Fe}^{2+}+\mathrm{Mg}^{2+}+\mathrm{H}_{2} \mathrm{O} \rightarrow \\
\left(\mathrm{Fe}_{14} \mathrm{Mg}_{12} \mathrm{Al}_{2.5}\right)\left(\mathrm{Al}_{0.7} \mathrm{Si}_{3.3}\right) \mathrm{O}_{10}(\mathrm{OH})_{8} \\
(\text { Potash feldspar })(\text { Chlorite })+\mathrm{SiO}_{2}+\mathrm{H}^{+}+\mathrm{K}^{+} .
\end{gathered}
$$

The braided river delta in the study area is mainly a set of metamorphic rocks (granitic gneiss, diorite gneiss, and hornblende gneiss) (Ding et al., 2010) with a large amount of biotite. Grain-coating chlorite began to grow as the formation temperature of the buried rocks increased (average $>35-55{ }^{\circ} \mathrm{C}$ ), as there has sufficient material source (Huggett et al., 2015). The parent rock types of the Chang 8 


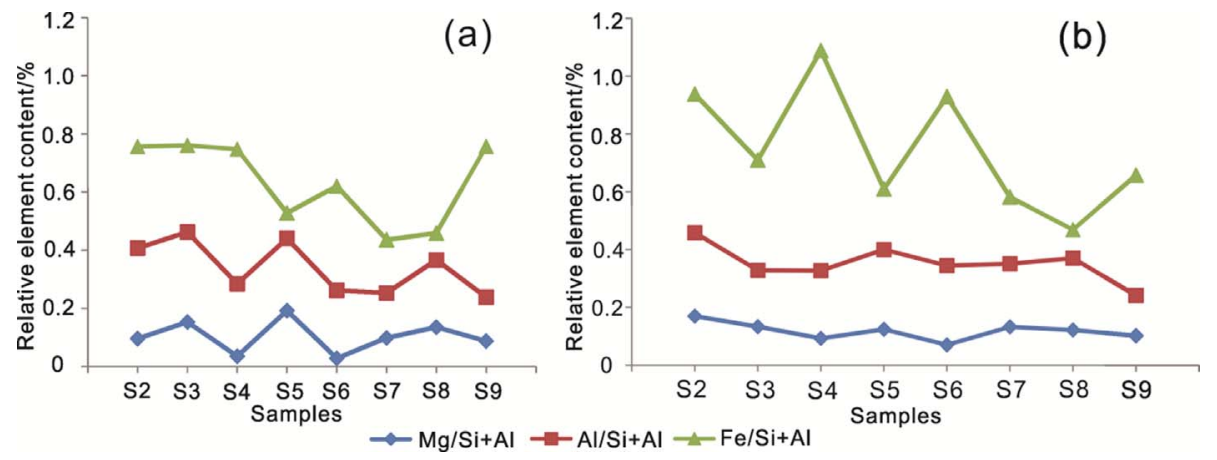

Fig. 5. Contents of Mg, Al, Si, Fe in different samples with (a) grain-coating chlorite and (b) pore-lining chlorite.

Member sandstone in the study area are mainly intermediate-basic volcanic rocks, phyllites and schists (Zhang et al., 2012). These rocks are rich in iron and magnesium materials which can be hydrolyzed to form a large amount of iron and magnesium ions during weathering and transportation. Provide a rich material source for the formation of grain-coating chlorite. Also, as the biotite and some of the iron-rich magnesia cuttings continued to hydrolyze and dissolve, and thus provided a large amount of iron and magnesium was provided to form the chlorite. The iron-rich colloid that was flocculated during the deposition period also underwent hydrolytic dissolution, and the feldspar particles in the study area dissolved to produce a large amount of iron and magnesium ions during the dissolution process. The above factors caused a continual increase in the iron content of the pore fluid within the sandstone, and when the high iron and magnesium ion content in the pore fluid reached a certain level, chlorite was precipitated from the alkaline pore water (Jeffry, 2001).

The biotite-rich parent rocks hydrolyzed to form a large amount of iron, and the iron entering the river water would flocculated due to the addition of electrolytes to form ironbearing sediments. These iron-bearing sediments provide abundant iron sources for the formation of chlorite rims during diagenesis. As seawater is rich in electrolytes, chlorite can be expected to form in the marine deltas (Huang et al., 2004; Jeffry, 2001). The Chang 8 Member contains a large amount of chlorite, which indicates that the water body at the time of formation may have been brackish. Saline water and the presence of electrolytes have been fully confirmed in the study of the source rocks, trace elements, and paleontology (Ding et al., 2010). Therefore, it can be concluded that the development of chlorite is spatially coupled with the sedimentary facies, rock composition, and lake water properties.

Energy dispersive spectroscopy analysis shows minimal differences in the $\mathrm{Mg}^{2+}$ and $\mathrm{Al}^{3+}$ contents of the graincoating chlorite and the pore-lining chlorite. The relative specific gravity of $\mathrm{Mg}^{2+}$ and $\mathrm{Al}^{3+}$ in grain-coating chlorite is distributed between $1.16-4.7 \%$ and $7.9-13.64 \%$, respectively. Moreover, the relative specific gravities of $\mathrm{Mg}^{2+}$ and $\mathrm{Al}^{3+}$ in pore-lining chlorite are distributed between $2.26-4.56 \%$ and $8.5-12.32 \%$, respectively. Furthermore, the relative iron ion content proportions in grain-coating chlorite and pore-lining chlorite were $11.55-29.55 \%$ and
13.25-29.94, respectively. The tendency of the chlorite lining to decrease or increase near the center of pore was not apparent (Fig. 5). These results indicated that the chlorite in study area formed predominantly in a semi-closed diagenetic system, with the introduction and extraction of ions.

The formation time of chlorite can be obtained by the spatial distribution relationship of the particles and authigenic chlorite. The following phenomena were observed: (1) a small amount of grain-coating chlorite is present at the contact point between particles and particles in pointline contact (Figs. 6a and 6b), and grain-coating chlorite is observed in the discontinuous pores that are surrounded by three or more particles (Figs. 6a and $6 \mathrm{~b}$ ). These phenomena indicate that the chlorite clay film was placed before the point-line contact and particle compaction. (2) Graincoating chlorite in authigenic chlorite (on which pore-lining chlorite is the outer layer), and rosette chlorite can be seen in the macropore (Figs. 3a-3c), which indicates that the formation time of chlorite (from early to late) occurred in the order grain-coating chlorite, pore-lining chlorite and finally rosette chlorite. (3) Authigenic quartz crystals are visible in the pore spaces outside the pore-lining chlorite, and a small amount of flaky chlorite is embedded in the quartz crystallites (Fig. 6c). This phenomenon indicates that the porelining chlorite was formed earlier than the spontaneous quartz. (4) The grain-coating chlorite on the surface of feldspar particles that have undergone intragranular dissolution still maintains its original appearance (Fig. 6d), which indicates that the grain-coating chlorite formation occurred earlier than the dissolution. Furthermore, a small amount of pore-lined chlorite grew within the feldspar dissolution pores, which indicates that the fluid in the pores continued to be conducive to the growth of authigenic chlorite following dissolution of the feldspar particles. According to the results of analysis, the formation of grain-coating chlorite began in the synsedimentary period after which it underwent continuous post-transformation; the pore-lining chlorite formed in the middle diagenetic $\mathrm{A}-\mathrm{B}$ period; and the rosette chlorite formed in the late diagenetic period (Jeffry, 2001; Tian et al., 2008).

The microscopic characteristics, occurrence states, and formation mechanisms of the different types of chlorite are shown in Table 2. The grain-coating chlorite mainly occurs on the surface of the pore wall in the form of microcrystals, and usually occurs in the form of a film of 

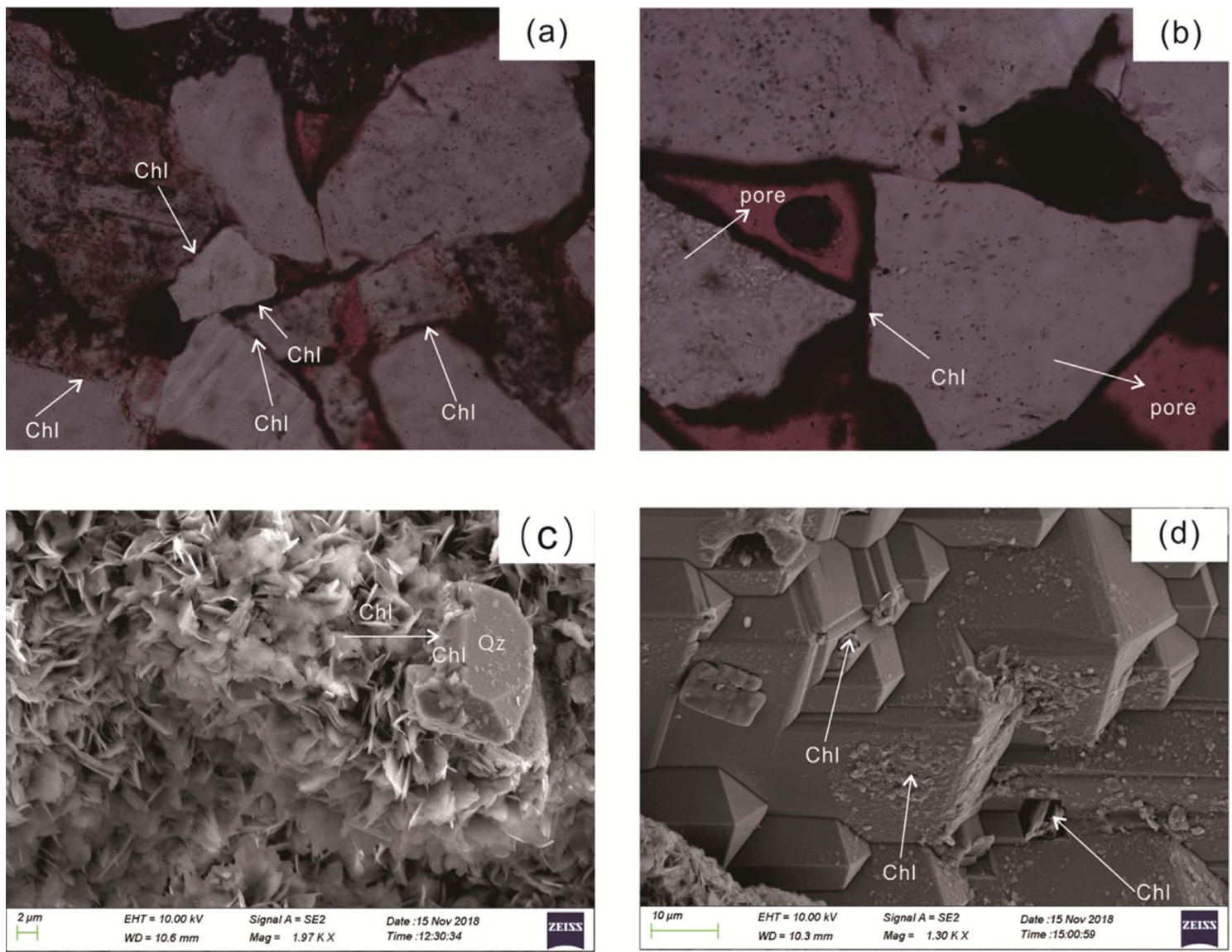

Fig. 6. FE-SEM and thin section pictures of chlorite and authigenic quartz. (a) There are a few chlorite rim or even no chlorite rim in the point-to-line contact of particles, and chlorite rim can still be seen in the unconnected pore surrounded by multiple particles, S4, $2174.53 \mathrm{~m}$; (b) At the site of intergranular pore development, chlorite rim is thicker and stained with particles, S8, 2287.45 m; (c) The authigenic quartz developed after the formation of pore-lining chlorite has a good crystalline form. A small amount of lamellar chlorite can be seen embedded in quartz crystals, a S3, $2192.6 \mathrm{~m}$; (d) Grain-coating chlorite develops on the surface of feldspar minerals, and lamellar chlorite develops in dissolution pore, $\mathrm{S} 2,2138.1 \mathrm{~m}$.

Table 2. Comparison of morphology and formation mechanism of different types of chlorite.

\begin{tabular}{lccc}
\hline Types & Location & Optical characteristics & Formation mechanism \\
\hline Grain-coating chlorite & $\begin{array}{c}\text { Mainly on the surface of } \\
\text { mineral particles }\end{array}$ & $\begin{array}{c}\text { On the surface of mineral } \\
\text { particles in a film of unequal } \\
\text { thickness with poor crystal } \\
\text { form }\end{array}$ & $\begin{array}{c}\text { The material source is mainly } \\
\text { from rivers and volcanic } \\
\text { clastics during the syn- } \\
\text { sedimentary process, such as } \\
\text { biotite dissolution; rich in Fe } \\
\text { and poor in } \mathrm{Mg}\end{array}$
\end{tabular}

Pore-lining chlorite

Mainly in intergranular pores and dissolved pores

Rosette chlorite

Mainly on the surface of
In intergranular pores and dissolution pores in the form of leaves with good crystal form mineral and pore-lining chlorite
On the surface of minerals as

agglomerates with good

crystal form and high degree of self-shape
The material source is mainly feldspar dissolution, rich in $\mathrm{Mg}$

The material source is mainly provided by feldspar

dissolution and mudstone compaction, with low $\mathrm{Fe}$ and $\mathrm{Mg}$ 
Table 3. Rock mineral composition of Chang 8 reservoir in Huaqing area.

\begin{tabular}{lcccccccc}
\hline Samples & Depths/m & Porosity/\% & $\begin{array}{c}\text { Permeability/ } \\
\times 10^{-3} \mu^{2}\end{array}$ & Quartz/\% & $\begin{array}{c}\text { Potash } \\
\text { feldspar/\% }\end{array}$ & Plagioclase/ & Calcite/\% & Chlorite/\% \\
\hline S2 & 2138.1 & 15 & 1.25 & 68.4 & 9.6 & 6.2 & - & 11.808 \\
S3 & 2192.6 & 11.08 & 0.521 & 50.3 & 13 & 20.1 & 1.9 & 7.747 \\
S4 & 2174.53 & 8.4 & 0.096 & 51.1 & 9.3 & 20.1 & 5.6 & 5.796 \\
S5 & 2242.4 & 10.2 & 0.406 & 60.1 & 16.5 & 12.5 & 0.8 & 7.227 \\
S6 & 2235.6 & 9.69 & 0.11 & 41.4 & 16.6 & 24.1 & 0.7 & 8.568 \\
S7 & 2062.2 & 11.18 & 0.74 & 64 & 9.1 & 15.2 & 0.6 & 7.125 \\
S8 & 2287.45 & 11.68 & 0.568 & 54.8 & 28.8 & 5.8 & 2.2 & 6.9 \\
S9 & 2189.4 & 13 & 0.524 & 60.7 & 20.8 & 7.2 & 0.9 & 7.968 \\
\hline
\end{tabular}

unequal thickness. It can be seen from the results of the energy-dispersive spectrum that this type of chlorite contains low Ti contents (Fig. 4a3); it is, therefore, speculated that, in addition to the large amount of iron-rich and magnesium substances carried by the river during syndeposition, material may also have come from the dissolution of volcanic debris such as biotite. In addition, the hydrolysis of intermediate-basic volcanic debris can also provide extensive material sources for the formation of grain-coating chlorite. The pore-lining chlorite forms throughout the entire diagenesis stage and is mainly distributed in the intergranular and dissolution pores. The crystal shape of the pore-lining chlorite differs; that which and formed close to the edge of the clastic particles during the early stage demonstrates poor crystalline shape, while that formed in the later stages near the center of the pores is markedly better. The energy dispersive spectrum results show no pyroclastic material. It is speculated that the material source may be related to the dissolution of feldspar and the introduction of fluid into the semi-open system. However, rosette chlorite is mainly distributed on the surface of particles in an agglomerated form, and its material source may be related to the local supersaturated microenvironment that resulted from the dissolution of feldspar and the removal of the pore water by the compaction of the overlying mudstone.

\subsection{The effect of authigenic chlorite on reservoir quality}

As shown in Figure 3 different types of chlorite occupy the pore walls in study area. Therefore, it is necessary to discuss the impact that chlorite has on the quality of the reservoir.

Many studies have investigated the effects of authigenic chlorite on reservoir quality (Baker et al., 2000; Berger et al., 2009; Chen et al., 2011; Ding et al., 2010; Ehrenberg, 1993; Huang et al., 2004; Liu et al., 2009; Liu and Li, 1996; Ma et al., 2017a, 2017b; Pittman, 1992; Salman et al., 2002; Yao et al., 2011). However, the protection mechanism of authigenic chlorite on the quality of the reservoir has been inconclusive. Although many scholars believe that the development of chlorite has a protective effect on the quality of reservoirs, the results have so far been inconclusive. This is because: (1) the grain-coating chlorite covering the surface of the particles can inhibit the secondary enlargement of authigenic quartz; (2) grain-coating chlorite could significantly improve the compaction resistance of a reservoir and preserve the primary pores; and (3) cement at the chlorite rim can hinder the contact between debris particles and pore water, thus reducing the precipitation of other forms of cement and preserving the intergranular pores. Previous studies have suggested that the development of grain-coating chlorite plays a positive role in preserving the primary pores in sandstone reservoirs. However, some scholars suggest that the development of authigenic chlorite, especially the development of porelining chlorite, can destroy the seepage capacity of a reservoir, leading to the deterioration of its quality. In this study, the mineral compositions of eight samples and eight additional samples were determined by XRD (Tab. 3 and Table A.1 (Appendix)). Diagrams describing the relationship between quartz, feldspar, and chlorite and porosity and permeability (Fig. 7) indicate that quartz content is positively correlated with porosity and permeability, with correlation coefficients of 0.626 and 0.735 (Figs. 7a1 and 7b1), respectively. The correlation coefficients between feldspar and porosity and permeability are 0.602 and 0.675 (Figs. $7 \mathrm{a} 2$ and $7 \mathrm{~b} 2$ ), and those associated with chlorite content are 0.602 and 0.574 (Figs. $7 \mathrm{a} 3$ and 7b3), respectively. These results indicate a significant correlation between the physical properties of a reservoir and the minerals present. The representation of the data indicates that authigenic chlorite has a good protective effect on porosity but a destructive effect on permeability. Thus, it is important to determine whether the actual situation is consistent with these data.

The sedimentary environment is the basic factor controlling the original physical properties. Most of the sand bodies that include grain-coating chlorite in the Ordos Basin mainly developed in subaqueous distributary channel micro facies located within the delta front. The grain-coating chlorite particles were thin and not easily precipitated when the water body oscillated during precipitation. The growth of chlorite also requires that iron and magnesium ions are provided by the formation fluid. Previous analysis (Fig. 5) has also indicated that the authigenic chlorite in this area formed within a semi-closed system within the formation fluid. However, it is unclear how it coated the surface of the particles. A comparison of the occurrence forms of the grain-coating chlorite and pore-lining chlorite showed that regeneration and growth of the grain-coating 

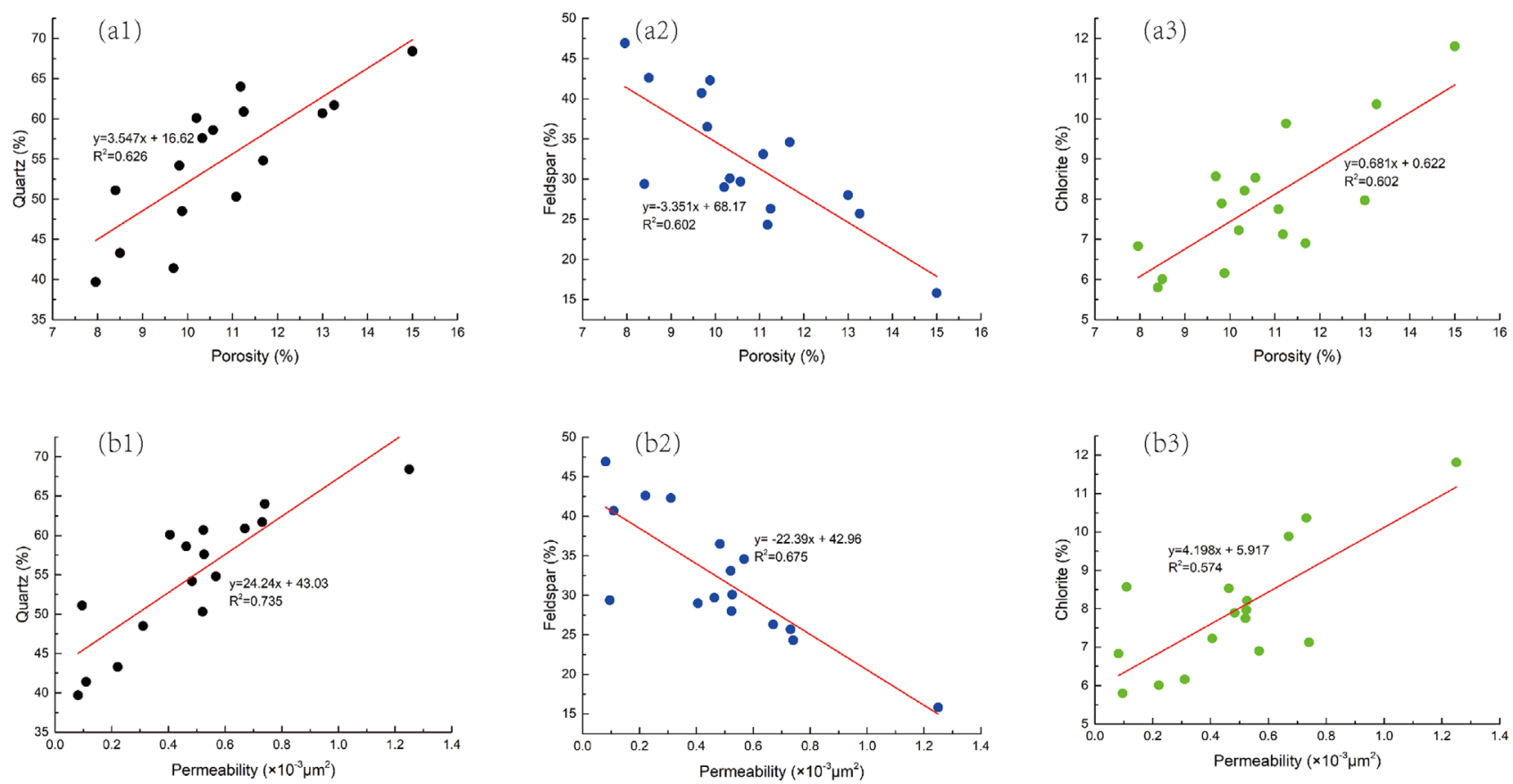

Fig. 7. Relationship between quartz, feldspar, chlorite and porosity and permeability (a1) - (b1) is the relationship between quartz and pore, permeability, respectively; (a2) - (b2) is the relationship between feldspar and pore, permeability, respectively; (a3) - (b3) is the relationship between chlorite and pore, permeability, respectively.

chlorite and the particle surface differ from those of authigenic quartz after the nucleus has formed on the surface of quartz particles. Precipitation onto the surfaces of particles is similar to the adsorption process of tight oil onto the surface of minerals and may occur as slow adsorption and precipitation in the form of a multilayer film. Microscopic analysis showed a smooth surface of grain-coating chlorite on the surface of particles after exfoliation, which agrees with the hypothesis of this study. The thickness of the grain-coating chlorite is generally $1-8 \mu \mathrm{m}$. Although its surface is relatively smooth, the formation of this chlorite can also lead to a reduction in the number of primary intergranular pores, destroying the physical properties of the primary reservoir. Pore-lining chlorite grows as a nucleus on the surface of the grain-coating chlorite and has a good crystal form with a thickness of 3-10 $\mu \mathrm{m}$. Its development in pore throats reduces the size of the pore and blocks the throat, which destroys the primary physical properties of sandstone reservoirs. In particular, the tortuosity of the pores and the throats is significantly increased when it develops as flakes or needles, causing fluid to seep into the throats. As a result, the flow state of the fluid in the throats changes, and flow around the chlorite surface becomes easier, reducing the flow capacity of the throat. The growth of chlorite in feldspar dissolution pores increases the roughness of the particle surface, fills the dissolution pores, reduces the reservoir space, and destroys the physical properties of the reservoir. The sedimentary environment controls the growth of the authigenic chlorite, which requires a certain amount of space for growth; when the original pores and permeability of the reservoir are good, the authigenic chlorite is well developed. The growth of grain-coating chlorite can improve the compaction resistance, but this effect is limited. Although grain-coating chlorite grows on the surface of particles, pore fluids can still communicate with the surface of particles through intercrystalline pores. However, the presence of grain-coating chlorite means that the growth of authigenic quartz can be reduced to a certain extent when it forms as a nucleus on the surface of the particles, which is confirmed by the fact that there is less authigenic quartz in areas where graincoating chlorite has developed. Pore-lining chlorite and the chlorite that grows in feldspar dissolution pores are important factors that cause a decrease in the number of original pores and subsequently affect the permeability of the reservoir. This indicates that the initial physical properties are mainly determined by the petrological characteristics of sand bodies that are deposited under strong hydrodynamic conditions (Berger et al., 2009; Worden et al., 2020). However, the development of authigenic chlorite does not preserve the primary pores; in contrast, it destroys them, particularly during the reconstruction of throats (Zhang et al., 2012; Ma et al., 2017a, 2017b).

\subsection{Micro-occurrence characteristics of tight oil in different types of chlorite}

According to the results of fluorescent thin sections and ESEM, the micro-occurrence states of tight oil that is related to authigenic chlorite can be divided into four types. (1) Tight oil is controlled by grain-coating chlorite as it forms as thin film in the intercrystalline pores on the surface of grain-coating chlorite, with particles and agglomerated particle leading to the formation of intercrystalline pores. (2) Tight oil is controlled by the presence of pore-lining chlorite as it forms in the form of a thin film within the 

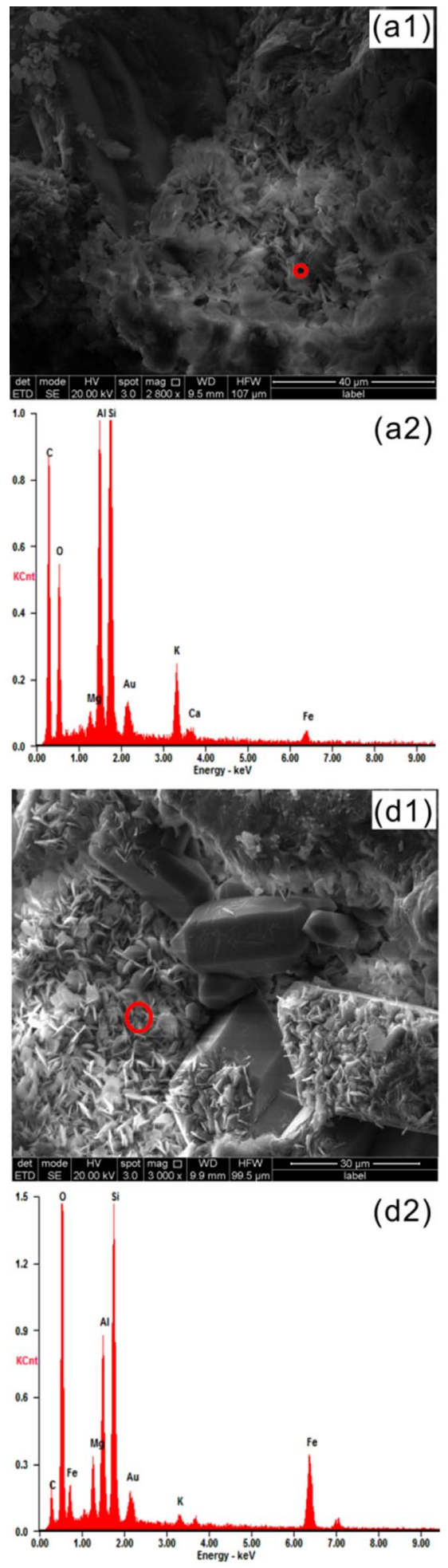
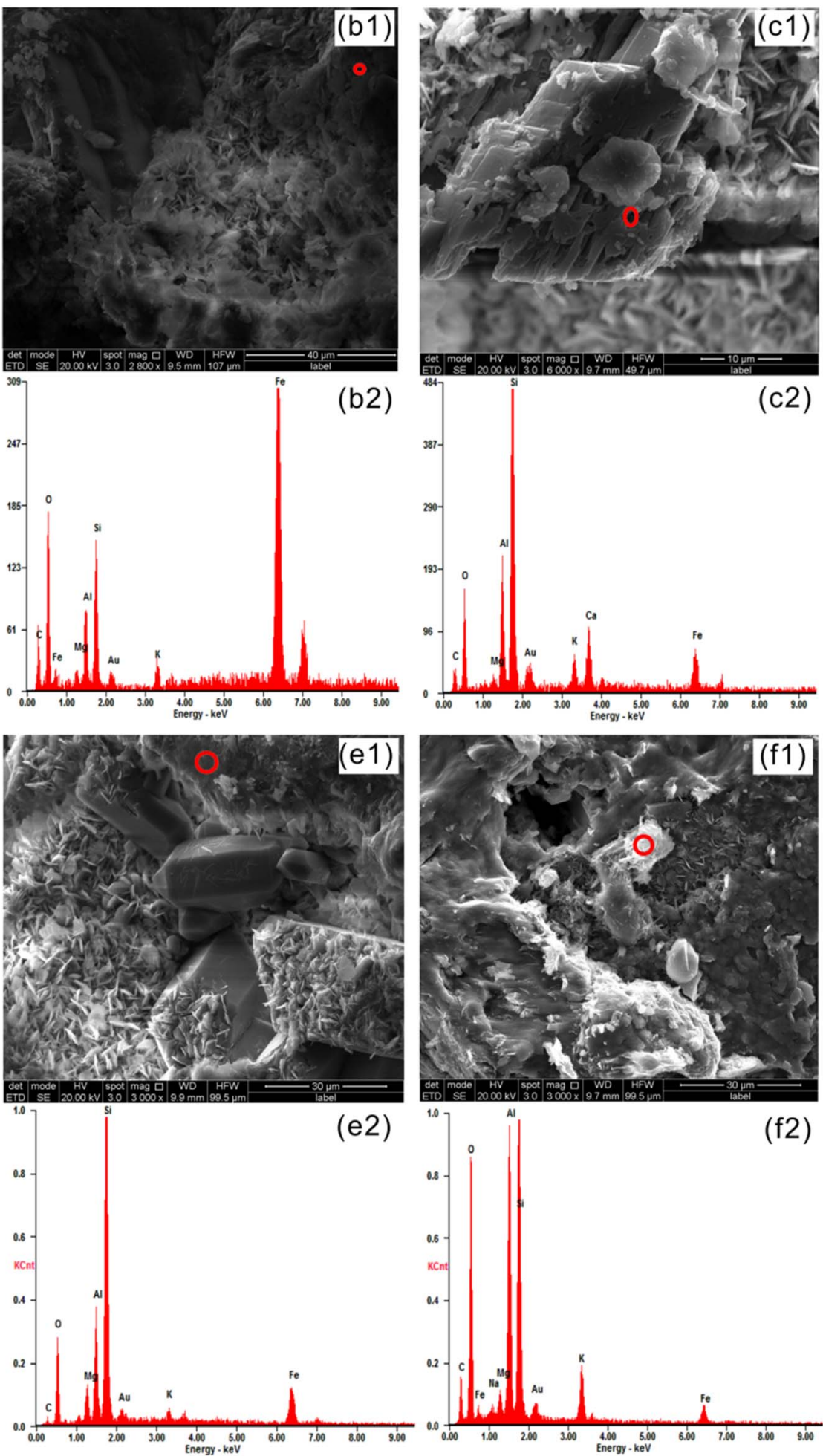

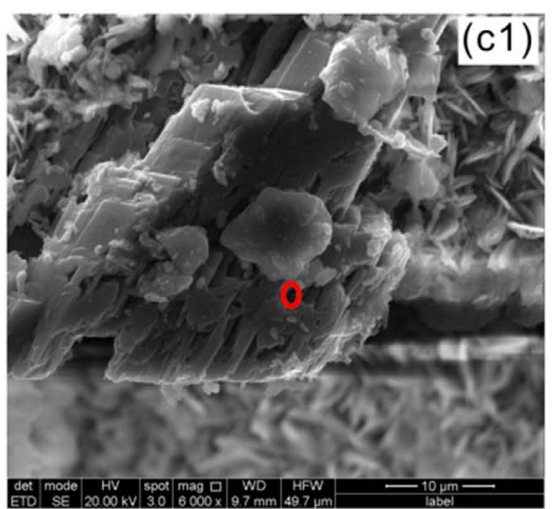

(c2)
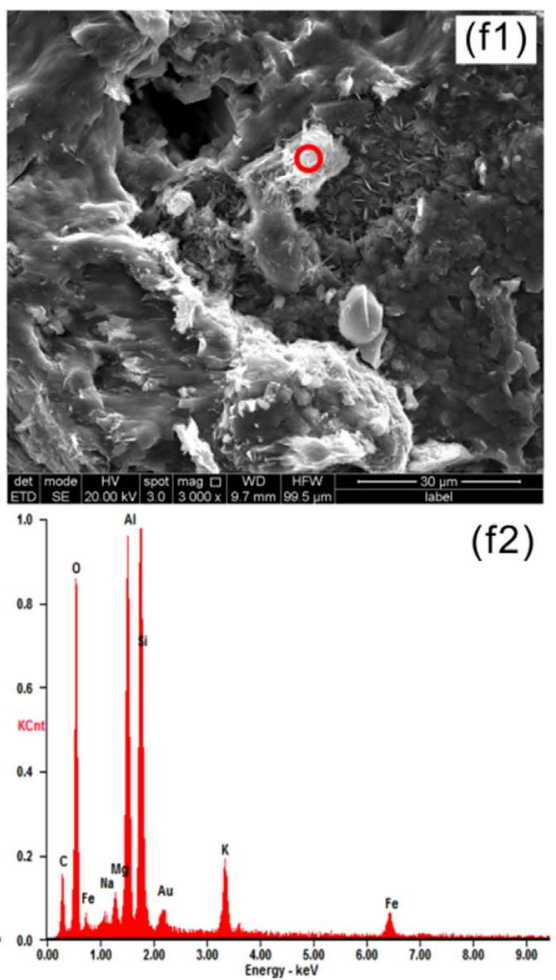

Fig. 8. Microscopic occurrence characteristics and EDS of tight oil in different occurrence conditions of chlorite.

intercrystalline pores located on the surface of porelining chlorite, with particles or agglomerated particles forming the intercrystalline pores. (3) Tight oil forms on the surface of the authigenic chlorite located within feldspar dissolution pores and its micro-occurrence are in the form of particle or agglomerated particles. (4) Tight oil is controlled by rosette chlorite that forms as particles or agglomerated particles. EDS was used to measure the carbon content of the tight oil on the surface of the grain-coating chlorite and pore-lining chlorite within feldspar dissolution pores, grain-coating chlorite intercrystalline pores, and pore-lining chlorite intercrystalline pores. Sample S8 was selected as 


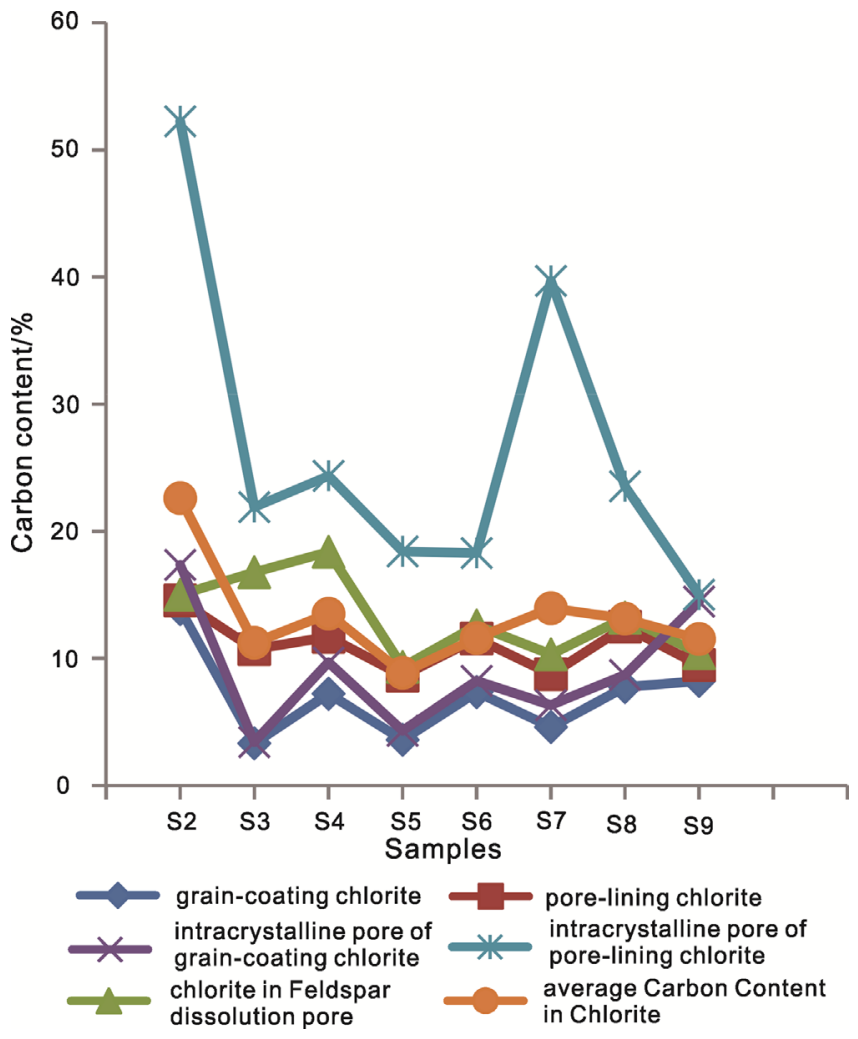

Fig. 9. Carbon content of chlorite in different occurrence states under EDS.

the research object for this analysis to avoid differences in the diagenesis and hydrocarbon filling processes that may occur in samples from different depths and horizons. The micro-occurrence characteristics of the tight oil were thus analyzed.

The grain-coating chlorite adsorption of tight oil mainly manifests the adsorption of tight oil on the surface of authigenic chlorite following the hydrocarbon filling that occurs at a later stages. ESEM indicates that this process mainly occurs on the surface of chlorite in the form of a thin film of unequal thickness (Fig. 8e1). A good reservoir is produced because the intercrystalline pores in the grain-coating chlorite are well developed, even though the intercrystalline pore spaces are small. The micro-occurrence of tight oil in the intercrystalline pores of grain-coating chlorite is in the form of particles or agglomerated particles with a dark ring edge (Fig. 8b1). The carbon content of the tight oil in the outer layer of the intercrystalline pores decreases toward the centre of the pores, which may be related to shrinkage that results from the volatilization and adsorption of the tight oil in the intercrystalline pores over time. Compared with other diagenetic minerals (such as quartz and feldspar), chlorite has a higher specific surface area and roughness can strongly adsorb tight oil and can be preserved in direct contact with the chlorite located around the intercrystalline pores. According to the results of the EDS, the carbon content on the surface and in the intercrystalline pores of grain-coating chlorite was $4.59 \%$ and $6.31 \%$, respectively (Figs. $8 \mathrm{e} 2$ and $8 \mathrm{~b} 2$ ). The carbon content is

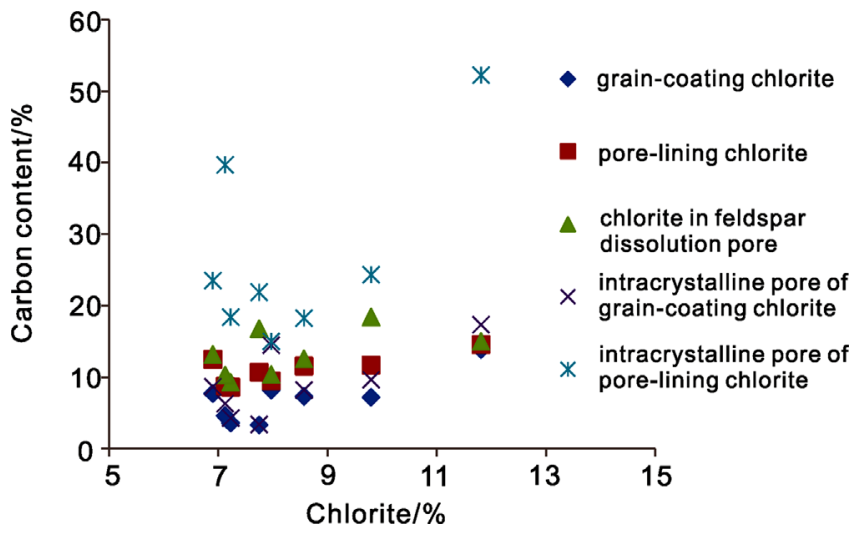

Fig. 10. The relationship between carbon content and chlorite content in different occurrence states under ESEM and EDS.

slightly higher in the intercrystalline pores than it is on the surface of the chlorite, which may be related to the smaller size of the intercrystalline pores and the higher adsorption capacity of chlorite as compared to tight oil.

Compared with grain-coating chlorite, pore-lining chlorite has a larger specific surface area, more adsorption sites, and a higher capacity to adsorbed tight oil. The changes in the reservoir pore-permeability transformation of the reservoir are evident because of the vertical growth of this form of chlorite. ESEM observation indicates that tight oil is mostly present as thin film on the leaf-like or needle-like crystal planes of the pore-lining chlorite, and occurs mostly in the form of strips or spots as leaf-like or needle-like crystals (Fig. 8d1). The intercrystalline pores associated with pore-lining chlorite are well developed and provide a suitable space for the occurrence of tight oil. Tight oil mainly occurs in a particle or agglomerated particle form within the intercrystalline pores (Fig. 8a1). According to the EDS results, the carbon contents in the pore-lining chlorite at the surface or within intercrystalline pore are $8.74 \%$ and $39.68 \%$, respectively (Figs. $8 \mathrm{~d} 2$ and $8 \mathrm{a} 2$ ), which may be related to the adsorption capacity of chlorite and the flow characteristics of tight oil in intercrystalline pores. The tight oil is adsorbed as it flows through the pore-lining of the chlorite surface, while the degree of detour is considerable because of the unique occurrence of pore-lining chlorite. Tight oil is quickly detained in the intercrystalline pores and eventually takes the occurrence form of particles or agglomerated.

Authigenic chlorite is present in granular form in feldspar dissolution pores; it grows in multiple directions in the pores and its development is controlled by the space available (Fig. 8c1). The ESEM results indicate that tight oil mostly occurs in particle or agglomerated particle form as thin films on the surface of chlorite. According to the results of the energy-dispersive spectrum, the carbon content on the surface of the chlorite was $10.39 \%$ (Fig. 8c2).

Rosette chlorite is rare in the study area, and tight oil is mainly present within intercrystalline pores in the form of particles or agglomerated particle. Fluorescent thin sections analysis indicates that it is deposited on the surface of the chlorite in the form of an oil film and on rosette chlorite as isolated or agglomerated particles. (Fig. 8f1). 


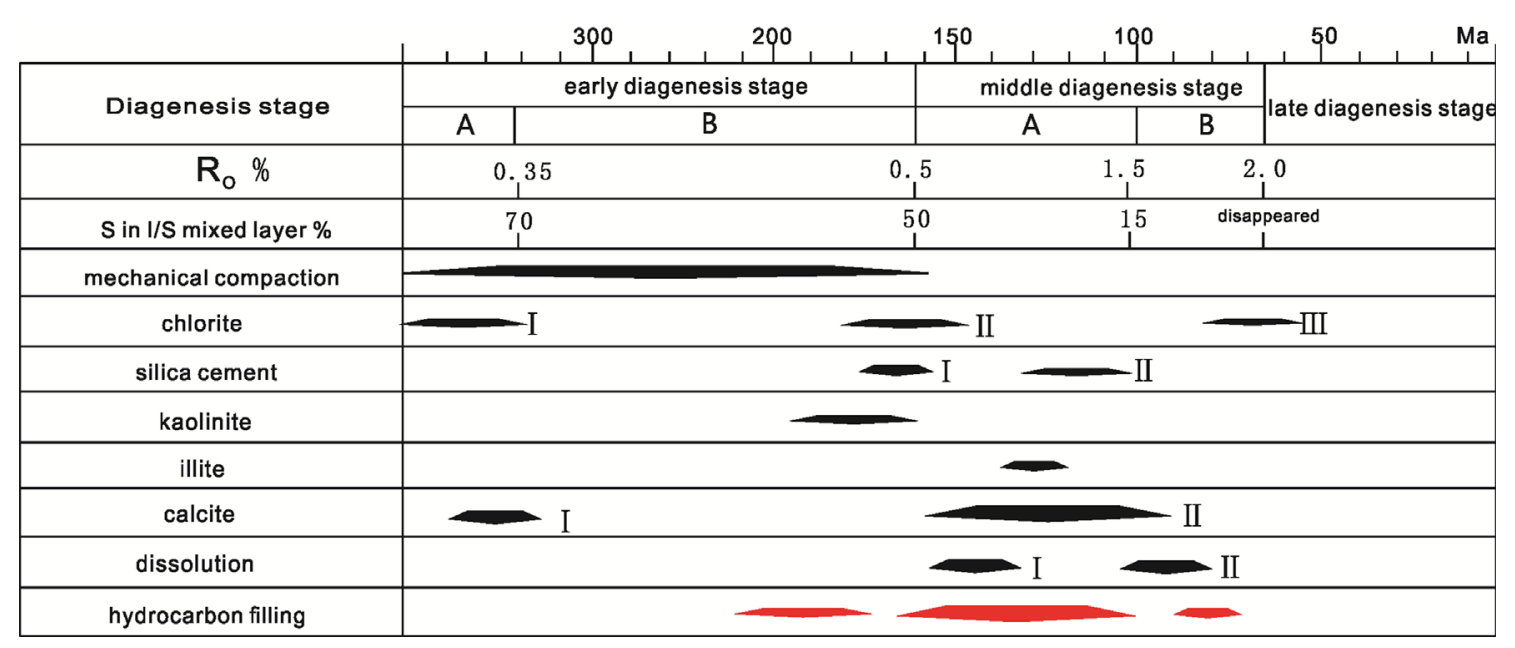

Fig. 11. Hydrocarbon filling time in Huaqing area.

Aggregates of agglomerated tight oil were apparent under the ESEM. The oil film is thicker on chlorite crystal forms than it is on grain-coating chlorite and pore-lining chlorite, and may occur spontaneously alongside the formation of the rosette chlorite. It has a large specific surface area with enormous adsorption potential and the carbon content of $12.74 \%$ (Fig. 8f2), which is higher than that observed in association with the grain-coating and porelining chlorite.

There are apparent differences in the adsorption capacity of the various chlorite forms that are associated with tight oil. The carbon contents in various forms are in the following order (from higher to lower): intercrystalline pores of pore-lining chlorite $>$ the surface of rosette chlorite $>$ the surface of authigenic chlorite in feldspar dissolution pores $>$ the surface of pore-lining chlorite $>$ intercrystalline pores of grain-coating chlorite $>$ the surface of grain-coating chlorite. Analysis of the carbon content on the chlorite surface and in the intercrystalline pores of its different occurrences (Figs. 9 and 10), indicates that the state in which authigenic chlorite occurs has noticeable control on the enrichment of tight oil, and there is little difference between the ion contents in the various states of authigenic chlorite; differences in the specific surface area that are related to its various states, therefore, lead to the differences in its capacity to adsorbed tight oil.

\subsection{Effect of authigenic chlorite on the adsorption and its micro-occurrence characteristics}

According to the burial-thermal evolutionary history of the Huaqing area in Ordos Basin (Guo et al., 2013; Luo et al., 2006), the hydrocarbon expulsion of the Yanchang Formation in the area occurred primarily during the period between the end of the Triassic and the end of the Early Jurassic (210-175 Ma), with three main hydrocarbonbearing fluid stages occurring in total: (1) the end of the Triassic to the end of the Early Jurassic (210-175 Ma); this stage resulted in a relatively low expulsion of hydrocarbons, (2) the end of the Middle Jurassic to the end of the Early
Cretaceous (165-100 Ma), during which the largest amounts of hydrocarbons were expelled, and (3) the period from the end of the Late Cretaceous to the end of the Early Paleogene (90-75 Ma).

The burial-diagenesis-hydrocarbon filling evolution process of the compact sandstones in the study area can be determined (Fig. 11). Based on the diagenesis characteristics and evolutionary diagenesis process of the sandstones in the different lithologies of Chang 8 Member combined with the burial-thermal evolution history (Fig. 12). The original intergranular pores were well developed during the same sedimentary stage, and pore fluid flowed smoothly within connected pores (Fig. 13a). With the change in the pore fluid properties, the original intergranular pores were continuously reformed and reduced, and the grain-coating chlorite began to precipitate from the synsedimentary stage. The pore-lining chlorite mainly developed in the early diagenetic B-the middle diagenetic A stage. Rosette chlorite is mainly developed in the middle-late diagenetic stage B. After the grain-coating chlorite formed in the early stage, the low maturity and compact oil did not fill the pores and throats. The pores and throats from this period have better connectivity and are preferentially filled by migration, with the results of fluorescent thin sections analysis indicating that the tight oil was absorbed onto the surface of grain-coating chlorite in the form of a thin film during this period (Fig. 13b). The tight oil adsorbed by this chlorite mainly has low maturity, contains strongly polar compounds (such as asphaltene and non-hydrocarbons), and demonstrates a strongly adsorptive viscous effect, enabling multi-layer adsorption and reducing the size of the pores and throats while also increasing the viscous resistance of the later fluid flow (Friis et al., 2014). The grain-coating chlorite that developed on the intercrystalline pores, early tight oil mainly has an unequal thickness and a ring edge (Fig. 13b(1)). During the second stage in the formation of pore-lining chlorite formation, a large amount of hydrocarbon filling occurred and tight oil mainly formed on the surface of chlorite and its intercrystalline pores in the thin film form, and as isolated or agglomerated particles 


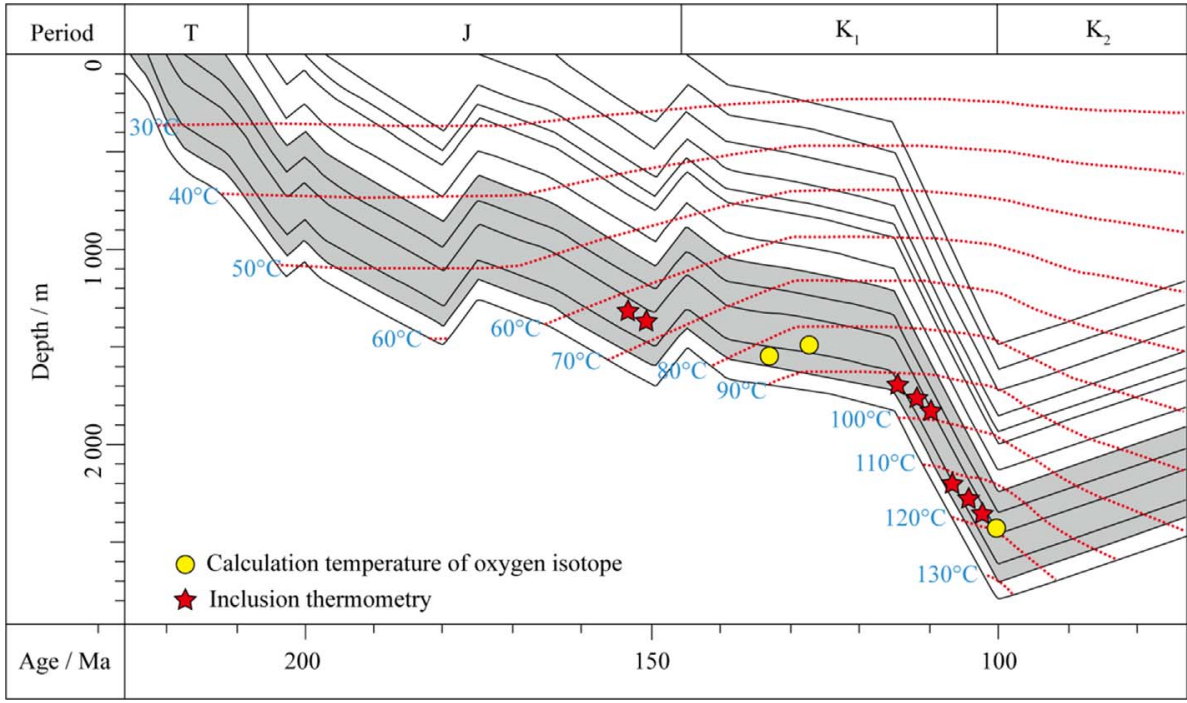

Fig. 12. The burial and thermal history of Chang 8 Member in the study area (according to Yang et al., 2018).
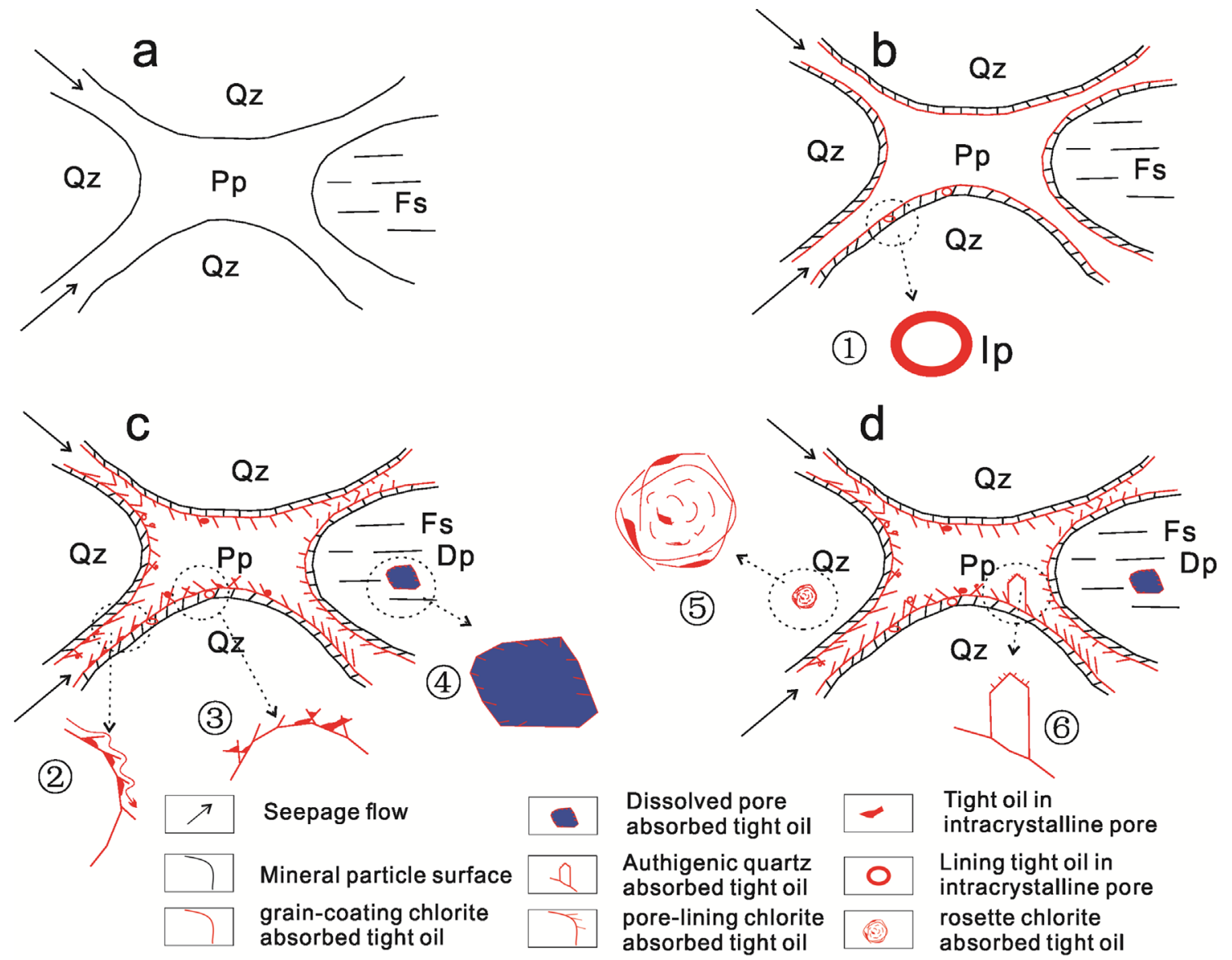
absorbed tight oil $\longrightarrow$ intracrystalline pore

Authigenic quartz Lining tight oil in absorbed tight oil $\quad 0$ intracrystalline pore pore-lining chlorite rosette chlorite absorbed tight oil absorbed tight oil

Qz:Quartz Fs:Feldspar IP:Intracrystalline pore Pp:Primary pore DP:Dissolved pore (1)-(6) is Partial enlargement schematic diagram

Fig. 13. The influence of authigenic chlorite on the micro-occurrence of tight oil during hydrocarbon filling. 
(Fig. 13c). During this period, the evolution of organic matter was in a lowly mature to a mature stage, which is the most active period for organic-inorganic reactions in source and reservoir rock systems. Many organic and inorganic acidic fluids formed, dissolving unstable aluminosilicate minerals such as feldspar, clay minerals, and early carbonate cement that were present within the sandstone, resulting in the formation of secondary pores. Compact oil was often present within the dissolution pores in the form of a ring edge before gradually filling the entire pore space (Fig. 13c (4). The increase in burial depth, temperature and pressure conditions and the continuous consumption of organic acids meant that a large amount of clay minerals were dehydrated, unstable minerals dissolved, and ion exchange processes occurred, which released many alkaline cations ( such as $\mathrm{K}^{+}, \mathrm{Na}^{+}$). This increased $\mathrm{pH}$ of the pore fluid and gradually changed the diagenetic environment to one that was weakly alkaline. As there were many iron and magnesium ions within the pore fluid, authigenic chlorite developed in dissolution pores and adsorbed tight oil, both onto the surface of chlorite and within its intercrystalline pores (Figs. 13c(3) and 13c(4)). The development of pore-lining chlorite further promoted the irregularity of mineral surfaces and enlarged specific surface areas, resulting in a significant increase in the local adsorption potential energy, which played a positive role in adsorption occuring between minerals and tight oil. During this process, with the continuous growth of pore-lining chlorite, the microflow of pore fluid in interconnected pores gradually changed from a stable liner to flow around the edge of particles. Local turbulence occurred, increasing the seepage resistance and enabling the easy formation of particular or agglomerated particle forms of tight oil, which accumulated in an opposite direction to the fluid flow in the pore-lining chlorite lamellar crystals (Fig. 13c(2)). The flow of fluid in the intercrystalline pores was thus blocked, and the microoccurrence state of tight oil enriched in particle and agglomerated particle forms was mainly occurred in the intercrystalline pores (Figs. 13c(2) and 13c(3)). For the development of rosette chlorite, the adsorption of authigenic chlorite onto the authigenic chlorite was predominantly in the form of a surface oil film (Fig. 13d). During this stage, the specific surface area of authigenic chlorite was higher; however, its tight oil adsorption capacity was low because of the minimal amount of tight oil produced during this stage and the limited development of authigenic chlorite. Only particles and agglomerated particle forms of tight oil occurred in areas such as intercrystalline pores (Fig. 13d(5)). At this stage, authigenic quartz developed mainly through the flow of pore fluids through the intercrystalline pores in the authigenic chlorite, and pore-lining chlorite then developed on the surface of the authigenic quartz (Fig. 13d(6). If hydrocarbons were able to freely flow through the quartz, tight oil was adsorbed onto the surface of authigenic quartz and chlorite. And the hydrocarbons preferentially filled the throats of well-connected pores. As chlorite minerals have a strong adsorption capacity for tight oil, tight oil preferentially formed an adsorption layer on the well-developed porous throat walls of the authigenic chlorite. In this respect, adsorption layers with thicknesses of 0.8-1.2 um, 1.5-2.2 um, and 2.3-2.8 um were generally formed on the grain-coating chlorite surfaces, pore-lining chlorite, and intercrystalline areas, and in secondary corrosion pores, respectively.

\section{Conclusion}

1. Authigenic chlorite mainly occurs in three forms in study area: grain-coating chlorite, pore-lining chlorite, and rosette chlorite. Grain-coating chlorite began to form in the synsedimentary period; pore-lining chlorite developed with a leaf- or needle-like shape in a direction vertical to that of the inner-coated pores during the middle diagenetic period; and rosette chlorite formed in the direction of the larger pores during the late diagenetic period.

2. The physical properties of sand bodies that are rich in authigenic chlorite are usually good because they are deposited under strong hydrodynamic conditions and have little relationship with grain-coating chlorite.

3. The micro-occurrence of tight oil can be divided into five types: emulsion form, throat form, cluster form, thin film form, and isolated $\mathrm{p}$ or agglomerated particles. The micro-occurrence states of tight oil on the surface of chlorite and in the intercrystalline pores are mainly controlled by the specific surface area and the local adsorption potential of the authigenic chlorite. However, there were no apparent differences in the adsorption capacities of the various chlorite forms in terms of carbon content, which is present in the following order (from high to low): intercrystalline pores of pore-lining chlorite $>$ rosette chlorite surfaces $>$ authigenic chlorite surface in feldspar dissolution pores $>$ pore-lining chlorite surface $>$ intercrystalline pores of grain-coating chlorite $>$ grain-coating chlorite surface.

4. In the process of hydrocarbon filling, different types of authigenic chlorite affect the micro-occurrence of tight oil. Tight oil mainly occurs on the surface of graincoating chlorite as thin film, and granular or agglomerated granular forms are mainly enriched within the intercrystalline pores. The thin film form is mainly enriched on pore-lining chlorite, on the surface of self-generated chlorite, and in the dissolution pores of agglomerated granules. Aggregates are mainly formed in the intercrystalline pores of the rosette chlorite.

5. Throughout the entire geological process, hydrocarbons preferentially fill the throats of well-connected pores, and tight oil preferentially forms an adsorption layer in the well-developed porous throat walls of authigenic chlorite. Furthermore, adsorption layers with thicknesses of $0.8-1.2 \mathrm{um}, 1.5-2.2 \mathrm{um}$, and 2.3-2.8 um, are generally formed on grain-coating chlorite, pore-lining chlorite in intercrystalline areas, and within secondary corrosion pores, respectively. 
Acknowledgments. The authors wish to acknowledge the Changqing Oil Field for providing the drill cores herein. We sincerely appreciate the financial support from the National Natural Science Foundation of China (Grant No. 42002175); we also appreciate financial support by the Research Funds for the Key Laboratory of Petroleum Resources Research, Gansu Province (Grant No. SZDKFJJ20201114), and the Major Science and Technology Programs of CNPC (Grant No. 2016E-05).

\section{References}

Al-Otaibi B.Z., Schechter D.S., Wattenbarger R.A. (2015) Production forecast, analysis and simulation of eagle ford shale oil wells, in: Paper presented at the SPE Middle East Unconventional Resources Conference and Exhibition, Muscat, Oman. SPE-172929.

Anjos S.M.C., De Ros L.F., Silva C.M.A. (1999) Chlorite authigenesis and porosity preservation in the upper cretaceous marine sandstones of the Santos Basin, Offshore Eastern Brazil, Blackwell Publishing Ltd, Hoboken, NJ.

Baker J.C., Havord P.J., Martin K.R., Ghori K.A.R. (2000) Diagenesis and petrophysics of the Early Permian Moogooloo Sandstone, southern Carnarvon Basin, Western Australia, AAPG Bull. 84, 2, 250-265.

Berger A., Gier S., Krois P. (2009) Porosity-preserving chlorite cements in shallow-marine volcaniclastic sandstones: Evidence from Cretaceous sandstones of the Sawan gas field, Pakistan, AAPG Bull. 93, 5, 595-615.

Billault V., Beaufort D., Baronnet A., Lacharpagne J.C. (2003) A nanopetrographic and textural study of graincoating chlorites in sandstone reservoirs, Clay Miner. 38, 3, $315-328$.

Chen G.J., Du G.C., Zhang G.C., Wang Q., Lv C.F., Chen J. (2011) Chlorite cement and its effect on the reservoir quality of sandstones from the Panyu low-uplift, Pearl River Mouth Basin, Petrol. Sci. 8, 2, 143-150.

Denne R.A., Hinote R.E., Breyer J.A., Kosanke T.H., Lees J.A., Engelhardt-Moore N., Spaw J.M., Tur N. (2014) The Cenomanian-Turonian Eagle Ford Group of South Texas: Insights on timing and paleoceanographic conditions from geochemistry and micropaleontologic analyses, Paleogeography 413, 2-28.

Ding X.Q., Zhang S.N., Ge P.L., Wan Y.L. (2010) Relationship between reservoir properties and chlorite rims: A case study from Yanchang formation of South Ordos Basin, North China, Geol. J. China Univ. 16, 02, 247-254. (in Chinese with English abstract).

Ehrenberg S.N. (1993) Preservation of anomalously high porosity in deeply buried sandstones by chlorite rims: Examples from the Norwegian Continental Shelf, AAPG Bull. 77, 1260-1286.

Friis H., Molenaar N., Varming T. (2014) Chlorite meniscus cement - implications for diagenetic mineral growth after oil emplacement, Terra Nova 26, 1, 14-21.

Fu J.H. (2018) Theory and technology of tight oil exploration in Ordos Basin, Science Press. (in Chinese with English abstract).

Gong Y.J., Liu S.B., Zhu R.K., Liu K.Y., Tang Z.X., Jiang L. (2015) Micro-occurrence of Cretaceous tight oil in southern Songliao Basin, NE China, Petrol. Explor. Develop. 42, 05, 681-688. (in Chinese with English abstract).
Grigsby J.D. (2001) Origin and growth mechanism of authigenic chlorite in sandstones of the Lower Vicksburg Formation, South Texas, J. Sediment. Res. 71, 1, 27-36.

Guo K., Zeng J.H., Liu T.T., Lei X. (2013) Hydrocarbon fluid flow stages and oil migration history in Yanchang formation of Longdong Area, Ordos Basin, Geoscience 27, 02, 382-388. (in Chinese with English abstract).

Heald M.T., Anderegg R.C. (1960) Differential cementation in the Tuscarora sandstone, J. Sediment. Res. 30, 4, 568-577.

Huang S.J., Xie L.W., Zhang M., Wu W.H., Shen L.C., Liu J. (2004) Formation mechanism of authigenic chlorite and relation to preservation of porosity in nonmarine Triassic reservoir sandstones, Ordos Basin and Sichuan Basin, China, J. Chengdu Univ. Technol.: Sci. Technol. Ed. 31, 3, 273-281. (in Chinese with English abstract).

Huangfu H.Y., Jiang Y., Yang G.J. (2003) Features of microscopic oil of Ordovician carbonate rock in Tahe-4 district, Xinjiang Geol. 21, 4, 495-496. (in Chinese with English abstract).

Huggett J.M., Burley S.D., Longstaffe F.J., et al. (2015) The nature and origin of authigenic chlorite and related cements in oligo-miocene reservoir sandstones, Tapti gas fields, Surat depression, Offshore Western India, J. Pet. Geol. 38, 4, 383-409.

Jeffry D.G. (2001) Origin and growth mechanism of authigenic chlorite in sandstones of the lower Vicksburg formation, South Texas, J. Sediment. Res. 71, 1, 27-36.

Jia C.Z., Zheng M., Zhang Y.F. (2012) Unconventional hydrocarbon resources in China and the prospect of exploration and development, Petrol. Explor. Develop. 39, 2, 129-136. (in Chinese with English abstract).

King H.M. (2019) Chlorite. On line encyclopedia at: https:// geology.com/minerals/chlorite.shtml.

Kuhn P.P., Primio R.D., Hill R., Lawrence J.R., Horsfield B. (2012) Three-dimensional modeling study of the lowpermeability petroleum system of the Bakken formation, AAPG Bull. 10, 1867-1897.

Lan Y.F., Huang S.J., Liang R., Zhang X. (2011) Influence of authigenic chlorite on the relationship of porosity to permeability in the sandstone reservoir: A case study from Chang- 8 oil-bearing formation of Triassic in Jiyuan-Huaqing area, Ordos Basin, J. Chengdu Univ. Technol. (Sci. Technol. Ed.) 38, 03, 313-320. (in Chinese with English abstract).

Landon S.M., Longman M.W., Luneau B.A. (2001) Hydrocarbon source rock potential of the Upper Cretaceous Niobrara Formation, Western Interior Seaway of the Rocky Mountain region, Mountain Geol. 1, 1-18.

LeFever J.A., LeFever R.D., Nordeng S.H. (2013) Reservoirs of the Bakken Petroleum System: A core-based perspective. Search and Discovery Article 10535.

Li J., Li J., Li Z.S., Zhang C.L., Cui H.Y., Zhu Z.L. (2018) Characteristics and genetic types of the Lower Paleozoic natural gas, Ordos Basin, Mar. Pet. Geol. 89, 106-119.

Liu Y.Q., Li W.H. (1996) Diagenetic characteristics and porosity evolution of the oil bearing arkoses in the Upper Triassic in the Eastern Shaan-Gan-Ning Basin, Acta Sedimentol. Sin. 14, 3, 87-96. (in Chinese with English abstract).

Liu J.K., Peng J., Liu J.J., Wang Y., Liu J.F. (2009) Pore-preserving mechanism of chlorite rims in tight sandstone: An example from the T3 $\times$ Formation of Baojie area in the transitional zone from the central to southern Sichuan Basin, Oil Gas Geol. 30, 1, 53-58. (in Chinese with English abstract. 
Luo J.L., Liu X.H., Lin T., Zhang S., Li B. (2006) Impact of diagenesis and hydrocarbon emplacement on sandstone reservoir quality of the Yanchang Formation (Upper Triassic) in the Ordos Basin, Acta Sedimentol. Sin. 80, 05, 664-673. (in Chinese with English abstract).

Ma P.J., Lin C.Y., Zhang S.Q., Dong C.M., Xu Y.F. (2017a) Formation of chlorite rims and the impact of pore-lining chlorite on reservoir quality: A case study from Shiqianfeng sandstones in upper Permian of Dongpu Depression, Bohai Bay Basin, eastern China, Australian J. Earth Sci. 64, 6, 825-839.

Ma P.J., Lin C.Y., Zhang S.Q., et al. (2017b) An overview on study of chlorite films in clastic reservoirs, J. Palaeogeogr. 19 , 1, 147-157.

Pittman E.D. (1992) Clay coats: occurrence and relevance to preservation of porosity in sandstones, SEPM Spec. Publ. 47, 241-255.

Pittman E.D., Lumsden D.N. (1968) Relationship between chlorite coatings on quartz grains and porosity, Spiro Sand, Oklahoma, J. Sediment. Res. 38, 2, 668-670.

Salman B., Robert H.L., Linda B. (2002) Anomalously high porosity and permeability in deeply buried sandstone reservoirs: Origin and predictability, AAPG Bull. 86, 301-328.

Shi J.A., Zhao X., Wang J.P., Wang Q., Lu L.F., Wang L., Wang Y.X. (2005) Geochemical characteristics of oils and extracts in different state from sandstone reservoir: I. Linear hydrocarbon, Acta Sedimentol. Sin. 23, 01, 162-169. (in Chinese with English abstract).

Sonnenberg A.S. (2015) The giant continuous oil accumulation in the Bakken Petroleum System, Williston Basin, AAPG Search Discov. Article 110220, 1-10.

Sonnenberg A.S. (2017) Keys to Niobrara and Codell Production, East Pony/Redtail Area, Denver Basin, Colorado, AAPG Search Discov. Article 10991, 1-3.

Sonnenberg A.S., Pramudito A. (2009) Petroleum geology of the giant Elm Coulee field, Williston Basin, AAPG Bull. 9, 1127-1153.

Sonnenberg S.A., Randy Ray R., O'Neal D., Dellenbach B., Finley E., Hinricher M. (2018) Introduction to special section: The Niobrara petroleum system, a multi basin resource play in the Rockies, Interpretation 6, 1, 2324-8866.

Tian J.F., Chen Z.L., Fan Y.F., Li P.P., Song L.J. (2008) The occurrence, growth mechanism and distribution of authigenic chlorite in sandstone, Bull. Mineral. Petrol. Geochem. 27, 2, 200-204. (in Chinese with English abstract).

Tong Z.G., He Q., Zhao Z.G. (2011) Analyzing hydrocarbon charges from hydrocarbon occurrences: A case of Pinghu oil and gas field in Xihu sag, East China sea, China Offshore Oil Gas 23, 3, 154-157. (in Chinese with English abstract).

Wang J.J., Pan C.C., Jiang L.L. (2010) Molecular and carbon isotope correlation of free, adsorbed and inclusion oils from the Carboniferous sandstone in the Tazhong-4 oilfield, Geochimica 39, 5, 479-490. (in Chinese with English abstract).

Wang M.L., Zhang S.A., Zhang F.D. (2015) Quantitative research on tight oil microscopic state of Chang 7 Member of Triassic Yanchang Formation in Ordos Basin, NW China, Petrol. Explor. Develop. 42, 6, 827-832.
Worden R.H., Griffiths J., Wooldridge L.J., et al. (2020) Chlorite in sandstones, Earth-Sci. Rev. 204, 103105.

Wu S.T., Zou C.N., Zhu R.K., Yao J.L., Tao S.Z., Yang Z., Zhai X.F., Cui J.W., Lin S.H. (2016) Characteristics and origin of tight oil accumulations in the Upper Triassic Yanchang Formation of the Ordos Basin, North-Central China, Acta Geological. Sin. 5, 1821-1837.

Wu S.T., Zhu R.K., Yang Z., Mao Z.G., Cui J.W., Zhang X.X. (2018) Distribution and characteristics of lacustrine tight oil reservoirs in China, J. Asian Earth Sci. 10, 1016.

Yang H., Zhang W.Z. (2005) Leading effect of the seventh member high-quality source rock of Yanchang Formation in Ordos basin during the enrichment of low-penetrating oil-gas accumulation - geology and geochemistry, Geochimica 37, 1, 59-64. (in Chinese with English abstract).

Yang W., Chen G.J., Zhang M.J., Li C.S., Lv C.C., Li C. (2012) Influence of authigenic chlorite on reservoir properties of Chang 8 Member set in Zhenbei area, Ordos Basin, Lithologic Reserv. 24, 03, 27-32 + 38. (in Chinese with English abstract).

Yang C., He Y.H., Ma F.X., Lei Y.H., Chen Y.G. (2018) Organic fluid activity times of Yanchang Formation in the southern Ordos Basin, Nat. Gas Geosci. 29, 5, 655-664.

Yao J.L., Wang Q., Zhang R., Li S.T. (2011) Forming mechanism and their environmental implications of chloritecoatings in Chang 6 sandstone (upper Triassic) of Hua-Qing Area, Ordos Basin, Acta Sedimentol. Sin. 29, 01, 72-79. (in Chinese with English abstract).

Zeng L., Wang L.S., Xu H.X., Jiao Y.G., Cui S.N., Han H., Zhang B.S. (2010) Petroleum Industrial Standard of People Republic of China: analysis method for clay minerals and ordinary nonclay minerals in sedimentary rocks by the X-Ray diffraction, $S Y / T$ 5163-2010, National Energy Administration, pp. 1-48.

Zhang X., Lin C.M., Cai Y.F., et al. (2012) Pore-lining chlorite cements in lacustrine-deltaic sandstones from the upper Triassic Yanchang formation, Ordos Basin, China, J. Pet. Geol. 35, 3, 273-290.

Zhou Y., Ji Y., Xu L., Che S., Niu X., Wan L., Zhou Y., Li Z., You Y. (2016) Controls on reservoir heterogeneity of tight sand oil reservoirs in Upper Triassic Yanchang Formation in Longdong Area, southwest Ordos Basin, China: Implications for reservoir quality prediction and oil accumulation, Mar. Pet. Geol. 78, 110-135.

Zou C.N., Zhu R.K., Bai B., Yang Z., Wu S.T., Su L., Dong D.Z., Li X.J. (2011) First discovery of nano-pore throat in oil and gas reservoir in China and its scientific value, Acta Petrol. Sin. 27, 6, 1857-1864. (in Chinese with English abstract).

Zou C.N., Tao S.Z., Yang Z., Yuan X.J., Zhu R.K., Hou L.H., Jia J.H., Wang L., Wu S.T., Bai B., Gao X.H., Yang H. (2012a) New advance in unconventional petroleum exploration and research in China, Bull. Mineral. Petrol. Geochem. 31, 4, 312-322. (in Chinese with English abstract).

Zou C.N., Yang Z., Tao S.Z., Li W., Wu S.T., Hou L.H., Zhu R.K., Yuan X.J., Wang L., Gao X.H., Jia J.H., Guo Q.L., Bai B. (2012b) Nano-hydrocarbon and the accumulation in coexisting source and reservoir, Petrol. Explor. Develop. 39, 1, 13-26. (in Chinese with English abstract). 


\section{Appendix}

\begin{tabular}{lcccccccc}
\hline Samples & Depths/m & Porosity/\% & $\begin{array}{c}\text { Permeability/ } \\
\times 10^{-3} \mu^{2}\end{array}$ & Quartz/\% & $\begin{array}{c}\text { Potash } \\
\text { feldspar/\% }\end{array}$ & Plagioclase/\% & Calcite/\% & Chlorite/\% \\
\hline SS1 & 2071.36 & 7.96 & 0.081 & 39.7 & 16.2 & 30.7 & 6.3 & 6.832 \\
SS2 & 2231.15 & 10.33 & 0.526 & 57.6 & 15.7 & 14.4 & 1.2 & 8.213 \\
SS3 & 2187.44 & 8.5 & 0.221 & 43.3 & 8.6 & 34 & 3.7 & 6.011 \\
SS4 & 2096.89 & 11.25 & 0.67 & 60.9 & 9.9 & 16.4 & 0.9 & 9.883 \\
SS5 & 2158.4 & 13.26 & 0.731 & 61.7 & 7.9 & 17.8 & 0.4 & 10.362 \\
SS6 & 2077.32 & 9.82 & 0.483 & 54.2 & 15.3 & 21.2 & 2.2 & 7.892 \\
SS7 & 2249.35 & 10.57 & 0.463 & 58.6 & 17.6 & 12.1 & 1.3 & 8.532 \\
SS8 & 2189.2 & 9.88 & 0.311 & 48.5 & 15.1 & 27.2 & 2.6 & 6.158 \\
\hline
\end{tabular}

